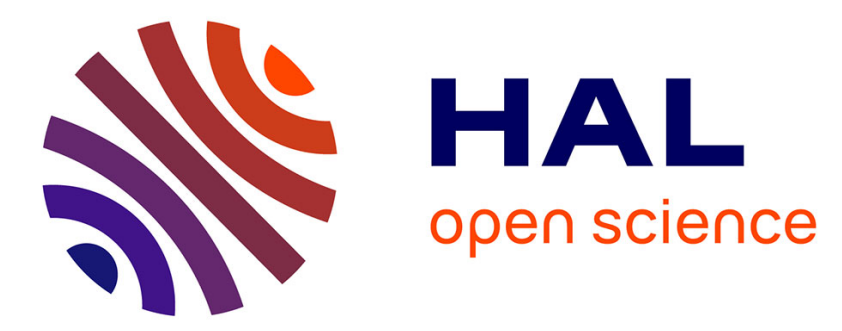

\title{
Driving the upper plate surface deformation by slab rollback and mantle flow
}

Pietro Sternai, Laurent Jolivet, Armel Menant, Taras Gerya

\section{To cite this version:}

Pietro Sternai, Laurent Jolivet, Armel Menant, Taras Gerya. Driving the upper plate surface deformation by slab rollback and mantle flow. Earth and Planetary Science Letters, 2014, 405, pp.110-118. 10.1016/j.epsl.2014.08.023 . insu-01064803

\section{HAL Id: insu-01064803 \\ https://hal-insu.archives-ouvertes.fr/insu-01064803}

Submitted on 17 Sep 2014

HAL is a multi-disciplinary open access archive for the deposit and dissemination of scientific research documents, whether they are published or not. The documents may come from teaching and research institutions in France or abroad, or from public or private research centers.
L'archive ouverte pluridisciplinaire HAL, est destinée au dépôt et à la diffusion de documents scientifiques de niveau recherche, publiés ou non, émanant des établissements d'enseignement et de recherche français ou étrangers, des laboratoires publics ou privés. 
Driving the upper plate surface deformation by slab rollback and mantle flow Pietro Sternai ${ }^{*}{ }^{1}$, Laurent Jolivet ${ }^{1}$, Armel Menant ${ }^{1}$ and Taras Gerya ${ }^{2}$

\footnotetext{
${ }^{1}$ Institut de Sciences de la Terre d'Orléans (ISTO) - University of Orléans, France

${ }^{2}$ Institute of Geophysics - Swiss Federal Institute of Technology (ETH), Zürich, Switzerland *Correspondence to: pietro.sternai@univ-orleans.fr
}

The relative contribution of crustal and mantle processes to surface deformation at convergent plate margins is still controversial. Conflicting models involving either extrusion mechanisms or slab rollback, in particular, were proposed to explain the surface strain and kinematics across the Tethyan convergent domain. Here, we present new high-resolution 3D thermo-mechanical numerical joint models of continental collision, oceanic subduction and slab tearing, which for the first time allow self-consistent reproduction of first-order Tethyan tectonic structures such as back-arc rifting and large-scale strike-slip faults accommodating continental escape. These models suggest that mantle flow due to slab rollback and tearing can modulate the surface strain and kinematics by locally enhancing trench retreat and dragging the upper plate from below. These results highlight the active role of the asthenospheric flow in driving the surface strain, not only by modulating the vertical stresses and producing dynamic topography but also through sub-horizontal motion. We discuss the implications of these findings based on observations across the Aegean-Anatolian and eastern Indian-Eurasian domains, though similar considerations may as well apply to other settings.

Keywords: slab tearing, slab rollback, mantle flow, surface deformation 


\section{Introduction}

Plate fragmentation, mountain building, formation of extensional basins, and major strike-slip fault zones characterized the long-term evolution of the Tethyan convergent domains (e.g., Ricou 1994). Surface deformation is classically attributed to either collision-related processes such as crustal shortening, extrusion and gravitational spreading (e.g., Tapponnier \& Molnar 1976; Le Pichon et al. 1992) or subduction-related mechanisms such as slab-pull, rollback and trench retreat (e.g., Dewey 1988; Royden 1993). However, subduction of the Tethyan lithosphere and collision along the African, Arabian, Indian and Eurasian margins often coexisted, interacting with each other to set jointly the surface kinematics and strain. For instance, oceanic subduction below the Hellenic domain coexisted with active convergence across the neighbouring Bitlis-Zagros region since approximately the late Oligocene (e.g., Sengör 1979; Jolivet \& Faccenna 2000; Allen et al. 2004). GPS measurements show a westward motion of Anatolia and a southward propagation of the Hellenic trench with respect to Eurasia (Reilinger et al. 2010), resulting in an overall counter-clockwise rotation (Figure 1a). Most of this rotation is accommodated by the north-Anatolian fault (NAF), a strike-slip fault zone joining the BitlisZagros domain to the east and the Aegean/Hellenic extensional back-arc region to the west (e.g., McKenzie 1972; Sengör 1979; Armijo et al. 1999). Tomographic models (Li et al. 2008) show a low-velocity anomaly below western Turkey, which was interpreted as a major tear in the Hellenic slab (De Boorder et al. 1998; Govers \& Wortel 2005) (Figure 1b). Recent studies foster the hypothesis that the mantle flow induced by slab rollback codetermines the surface deformation (Faccenna et al. 2006; Jolivet, Faccenna \& Piromallo 2009; Pérouse et al., 2012; Faccenna et al., 2013; Jolivet et al., 2013). 


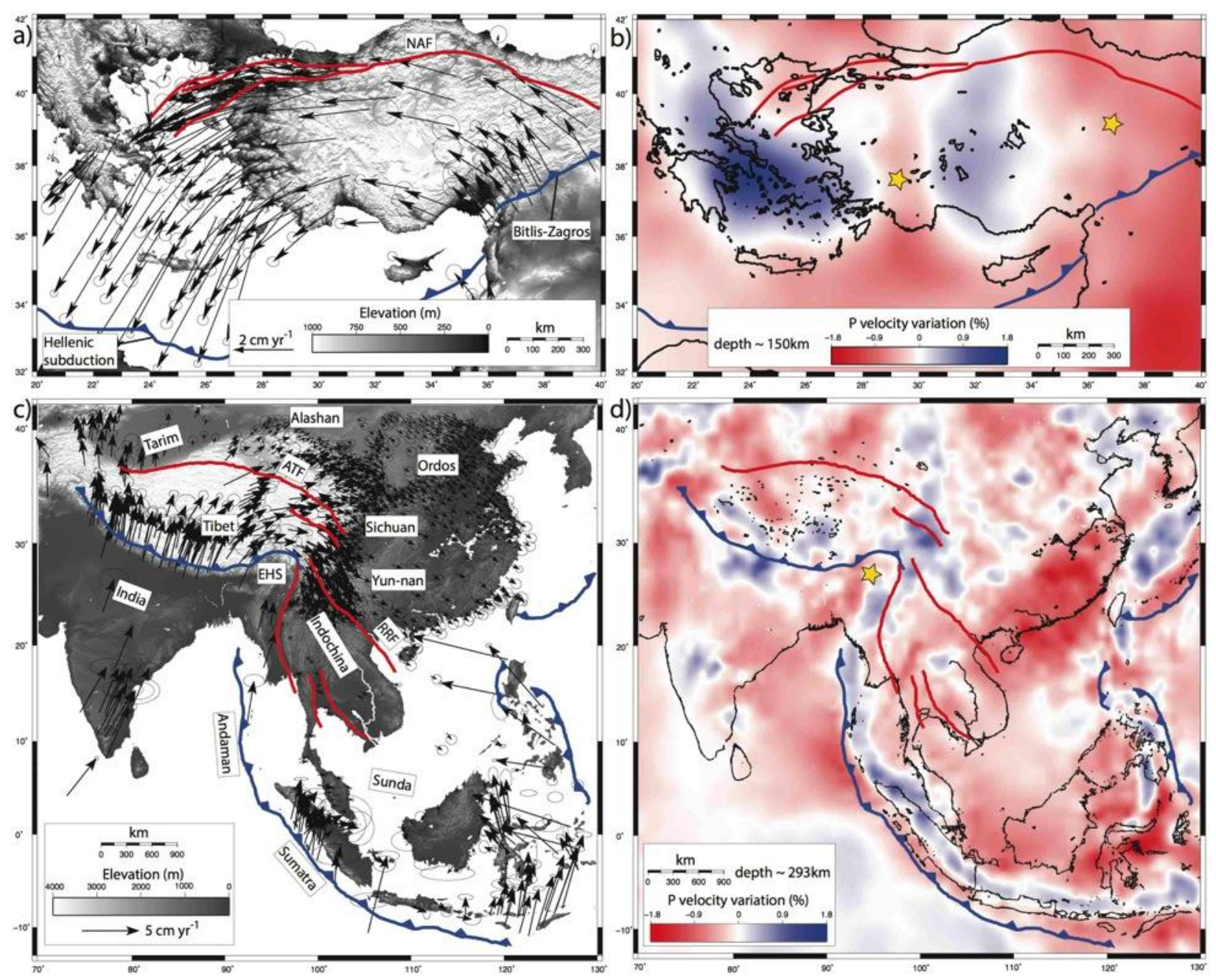

Figure 1: Maps of the Aegean-Anatolian and Indian-Eurasian systems. a,c) Topography and GPS velocities with 95\% confidence ellipses (Zhang et al. 2004; Gan et al. 2007; Reilinger et al. 2010). b,d) Tomographic models (Li et al. 2008) showing the Vp anomalies at the depths indicated. Stars show the locations of slab tears. Red and blues lines in all panels represent the major strike-slip fault zones and thrusts and subduction fronts, respectively.

Another example spanning larger scales and a longer temporal evolution is southeastern Asia in which collision of India with Eurasia and the Andaman-Sumatra subduction contribute jointly to surface deformation across the Himalaya, Indochina and Indonesia since $\sim 45$ Ma (e.g., Royden 1997; Tapponnier et al. 2001; Royden , Burchfiel \& van der Hilst 2008; 
Replumaz et al. 2013). Geodetic measurements relative to stable Eurasia show a prominent clockwise rotation around the Eastern Himalayan Syntaxes (EHS) characterized by eastward motion of eastern Tibet and western Sichuan, south-eastward motion in northern Yunan and south to south-eastward motion in southern Yunan (Zhang et al. 2004; Gan et al. 2007; ArRajehi et al. 2010) (Figure 1c). Several strike-slip fault zones, which arrange from the convergent domain north of Tibet, such as the Altyn-Tagh Fault, to the extensional domain east and south of it, such as the Red River Fault (RRF), accommodate the majority of this motion (e.g., Molnar \& Tapponnier 1975; Tapponnier \& Molnar 1976). Several basins, such as the South China Sea, have developed east of Tibet and offshore the Indochina peninsula in the Oligocene and Miocene (Tapponnier et al. 1982; Taylor \& Hayes 1983; Tapponnier et al. 1986). The main direction of extension across these regions was $\mathrm{N}-\mathrm{S}$ and the relationships between the formation of these basins and large-scale shear zones such as the RRF have been widely debated: these topographic lows formed either as a pull-apart basin at the south-easternmost extremity of the RRF (i.e., extrusion: e.g., Tapponnier et al. 1982; Tapponnier et al. 1986) or as more classical back-arc basins behind the retreating subduction (i.e., slab retreat: e.g., Taylor \& Hayes 1983; Jolivet, Tamaki \& Fournier 1994; Fournier et al. 2004). The deep mantle structures associated with subduction of ancient Tethyan lithosphere vary significantly along the collision boundary (Figure 1d). In particular, while deep and shallow slabs may be still (spatially) connected in the central Himalayas ( $\mathrm{Li}$ et al. 2008), there is no evidence for such a connection beneath the eastern Himalayas. Tomographic images show a low velocity zone below the EHS at depth larger than 200km separating the Indian and Andaman-Sumatra slabs (Li et al. 2008). This slab tear might have facilitated southward to westward rollback of the Andaman-Sumatra subduction after the onset of collision between India and Eurasia, and the mantle flow through the slab window and around the EHS might have codetermined the surface strain (Figure 1c,d) (Holt 2000). 
Conflicting models involving extrusion tectonics originated by the Arabia/India-Eurasia collision or rollback of the Tethyan torn slabs were proposed to explain the surface strain and kinematics across both the Aegean-Anatolian and eastern Himalayan regions (e.g., Tapponnier \& Molnar 1976; Tapponnier et al. 1986; Jolivet et al. 1990; Royden 1997; Armijo et al. 1999; Fournier et al. 2004; Becker \& Faccenna 2011). In addition, slab rollback is often proposed as a passive source of space to accommodate extrusion (e.g., Tapponnier et al. 1982; Armijo et al. 1999). However, the southward migration of the Hellenic trench is sensibly faster than the westward motion of Anatolia (Reilinger et al. 2010) (Figure 1a), and classical extrusion models fail in predicting widespread extension such as that across the Ordos, Sichuan, Yunan regions in absence of a "free boundary" (e.g., Jolivet et al. 1990; Jolivet, Tamaki \& Fournier 1994; Royden 1997; Wang et al. 2001). These flaws suggest that slab rollback is in fact an active player and not just a passive source of space.

These geological, geophysical and geodetic observations, which provide insights on the long-term and recent geologic history, can constrain self-consistent three-dimensional (3D) numerical thermo-mechanical geodynamic models in order to achieve a first-order quantification of the relative contribution of the deep and shallow dynamics in setting the surface deformation across convergent plate boundaries. Previous numerical studies demonstrated along trench variations and complex mantle and crustal processes and surface deformation in subductioncollision systems (e.g., van Hunen \& Allen 2011; Capitanio \& Replumaz 2013; Li et al. 2013; Duretz et al. 2014). Although some implications for the large-scale tectonics across the Tethyan domain have been suggested (Li et al. 2013; Duretz et al. 2014), the relative contributions of crustal and mantle flow processes to surface deformation remained widely unaddressed.

\section{Methods}

The purpose of this paper is to assess the relative contributions of the lithospheric and 
mantle dynamics in setting the surface deformation at the transition between collisional and subduction domains. To this aim, we use 3D Cartesian thermo-mechanical modeling to resolve self-consistently the joint effects of oceanic subduction, slab tearing and continental collision on mantle flow and surface deformation at high resolution and accounting for realistic crustal and mantle rheologies. In addition to the reference model setup and boundary conditions, we outline below some of the principal features of the numerical model, but more detailed information can be found in Gerya \& Yuen (2007), Zhu et al. (2009), Gerya (2010) and Li et al. (2013). Details on the parametric study can be found in the Supplementary Material.

\subsection{D numerical model, setup and boundary conditions}

All numerical experiments were performed with the code "I3ELVIS" (Gerya 2010), solving the momentum, continuity and energy equations based on a staggered finite difference scheme combined with a marker-in-cell technique. Realistic and non-Newtonian visco-plastic rheologies (Ranalli 1995) are used in the model. The model domain (Figure 2) measures 2000x328x1000 km in the $\mathrm{x}, \mathrm{y}$ and $\mathrm{z}$ dimensions, respectively. This domain is resolved by $501 \times 165 \times 197$ grid points resulting in a resolution of 4, 2 and $5 \mathrm{~km}$ in the $\mathrm{x}, \mathrm{y}$ and $\mathrm{z}$ dimensions, respectively. $~ 130$ million randomly distributed markers are used for advecting the material properties and temperatures. The velocity boundary conditions are free slip at the top $(\mathrm{y}=0 \mathrm{~km})$ and at both the front and back boundaries $(\mathrm{z}=0 \mathrm{~km}$ and $\mathrm{z}=1000 \mathrm{~km})$. The left and right boundaries $(\mathrm{x}=0 \mathrm{~km}$ and $\mathrm{x}=2000 \mathrm{~km})$ use constant $\mathrm{x}$-parallel velocities, which define the material influx. Global mass conservation is ensured by material outflux through the lower permeable boundary $(y=328 \mathrm{~km})$. The top surface of the lithosphere is calculated dynamically as an internal free surface through a $12 \mathrm{~km}$ thick layer of "sticky air" (Gerya 2010). Surface processes are implemented using a highly simplified gross-scale erosion-sedimentation law according to which instantaneous erosion limits mountains height to $4 \mathrm{~km}$ above the reference water level $(\mathrm{y}=12 \mathrm{~km})$, 
whereas instantaneous sedimentation limits trench depth to $8 \mathrm{~km}$ below the water level (Gerya \& Yuen 2007). The initial temperature gradient in the asthenospheric mantle is $\sim 0.5^{\circ} \mathrm{C} \mathrm{km}^{-1}$ (adiabatic). The thermal boundary conditions are $0^{\circ} \mathrm{C}$ for the upper boundary and nil horizontal heat flux across the vertical boundaries. An infinity-like external temperature condition (Gerya 2010) is imposed on the lower boundary. All the numerical experiments were performed using 20 cores on the BRUTUS cluster at the ETH-Zürich (the approximate run time of a simulation is two weeks).

\subsection{A joint model of continental collision, oceanic subduction and slab tearing}

Our numerical experiments were not designed to reproduce any particular case, but can be applied to the transition between a continental indenter flanked by active oceanic subduction. We stress that the ultimate goal of our numerical experiments is to investigate the effects of slab tearing on the mantle and surface strain, but the potential causes of a tear in the slab are beyond the scope of this work. As such, we impose mechanical weaknesses in the oceanic plate and spatial variations of the upper continental crust (as detailed below), but do not claim that, in natural contexts, slab tears are necessarily generated by these factors.

The reference model is set up as follows. Three continental plates $(\mathrm{C} 1, \mathrm{C} 2$ and $\mathrm{C} 3)$ are included into the initial model domain (Figure 2a and Table 1). 


\begin{tabular}{|c|c|c|c|c|c|c|c|c|c|c|}
\hline \multicolumn{11}{|c|}{ Material properties used in the numerical experiments } \\
\hline Material & $\begin{array}{c}k \\
\left(W^{-1} \mathbf{K}^{-1}\right)\end{array}$ & $\begin{array}{c}\rho_{0} \\
\left(\mathrm{~kg} \mathrm{~m}^{-3}\right)\end{array}$ & $\begin{array}{c}\mathrm{C}_{\mathrm{p}} \\
\left(\mathrm{J} \mathrm{kg}^{-1} \mathrm{~K}^{-1}\right)\end{array}$ & $\begin{array}{c}\mathrm{E}_{\mathrm{a}} \\
\left(\mathrm{kJ} \mathrm{mol}^{-1}\right)\end{array}$ & $\begin{array}{c}V_{2} \\
\left(\mathrm{~m}^{3} \mathrm{~mol}^{-1}\right)\end{array}$ & $\mathrm{n}$ & $\begin{array}{c}\eta_{0} \\
\left(\mathrm{~Pa}^{n} \mathrm{~s}\right)\end{array}$ & $\begin{array}{c}\mathrm{Hr} \\
\left(\mathrm{mW} \mathrm{m}^{-3}\right)\end{array}$ & $\begin{array}{l}\text { Viscous } \\
\text { flow law }\end{array}$ & $\sin \left(\phi_{\mathrm{etr}}\right)$ \\
\hline Sticky-air & 20 & 1 & 100 & 0 & 0 & 1 & $1 \times 10^{19}$ & 0 & Air & 0 \\
\hline Water & 20 & 1000 & 3330 & 0 & 0 & 1 & $1 \times 10^{15}$ & 0 & Water & 0 \\
\hline Sediment & $0.64+807 /(T+77)$ & 2600 & 1000 & 154 & 8 & 2.3 & $1.97 \times 10^{17}$ & 2 & Wet Qz. & 0.15 \\
\hline $\begin{array}{l}\text { Cont. crust } \\
\text { (C1, C3) }\end{array}$ & $0.64+807 /(T+77)$ & 2750 & 1000 & 154 & 8 & 2.3 & $1.17 \times 10^{17}$ & 2 & Wet Qz. & 0.15 \\
\hline $\begin{array}{l}\text { Cont. crust } \\
\text { (C2) }\end{array}$ & $1.18+807 /(T+77)$ & 2950 & 1000 & 238 & 8 & 3.2 & $4.8 \times 10^{22}$ & 2 & Wet $Q z$. & 0.15 \\
\hline Oc. crust & $1.18+474 /(T+77)$ & 3000 & 1000 & 238 & 8 & 3.2 & $4.8 \times 10^{22}$ & 0.25 & Wet Qz. & 0.15 \\
\hline Mantle & $0.73+1293 /(T+77)$ & 3300 & 1000 & 532 & 8 & 3.5 & $3.98 \times 10^{10}$ & 0.02 & Dry Ol. & 0.6 \\
\hline Weak zone & $0.73+1293 /(T+77)$ & 3300 & 1000 & 47 & 8 & 4 & $5 \times 10^{20}$ & 0.05 & Wet OI. & 0 \\
\hline
\end{tabular}

Table 1: Qz. and Ol. correspond to the abbreviations of Quartzite and Olivine. k denotes the thermal conductivity, $\rho_{0}$ is the density, $\mathrm{C}_{\mathrm{p}}$ is the specific heat capacity, $\mathrm{E}_{\mathrm{a}}$ is the activation energy, $\mathrm{V}_{\mathrm{a}}$ is the activation volume, $\mathrm{n}$ is the stress exponent, $\eta_{0}$ is the reference viscosity, $\mathrm{Hr}$ is the radiogenic heat production, $\square \phi_{\text {eff }}$ is the effective internal friction angle. Cohesion is $1 \mathrm{MPa}$ for each phase.

The crust of $\mathrm{C} 2$ and $\mathrm{C} 3$ are $50 \mathrm{~km}$ and $45 \mathrm{~km}$ thick, respectively. By varying the crustal thickness of the upper plate (C1) along the trench-parallel direction (z) one can control the slab descent rates (Nikolaeva et al. 2010) and therefore generate a tear in the slab. In particular, we imposed the crust of $\mathrm{C} 1$ as $35 \mathrm{~km}$ thick where $\mathrm{z} \leq 490 \mathrm{~km}$ and $45 \mathrm{~km}$ thick where $\mathrm{z}>510 \mathrm{~km}$ (linear interpolation in between). The initial thermal structure of $\mathrm{C} 1, \mathrm{C} 2$ and $\mathrm{C} 3$ is laterally uniform with $0^{\circ} \mathrm{C}$ at the surface and $1300^{\circ} \mathrm{C}$ at 90,140 and $150 \mathrm{~km}$ depth respectively. An oceanic domain, characterized by a trench-parallel weak fracture zone to initiate subduction and a trenchperpendicular weak fratcure zone to allow for slab tearing, separates the three continental plates (Figure 2a,b). The thermal structure of the oceanic lithosphere is that of a half-space cooling age of 120Ma (e.g., Turcotte \& Schubert 2002). Uniform and constant in time x-parallel velocities equal to $\sim 1.8 \mathrm{~cm} \mathrm{yr}^{-1}$ (convergence) are imposed to the $\mathrm{x}=2000 \mathrm{~km}$ boundary. 


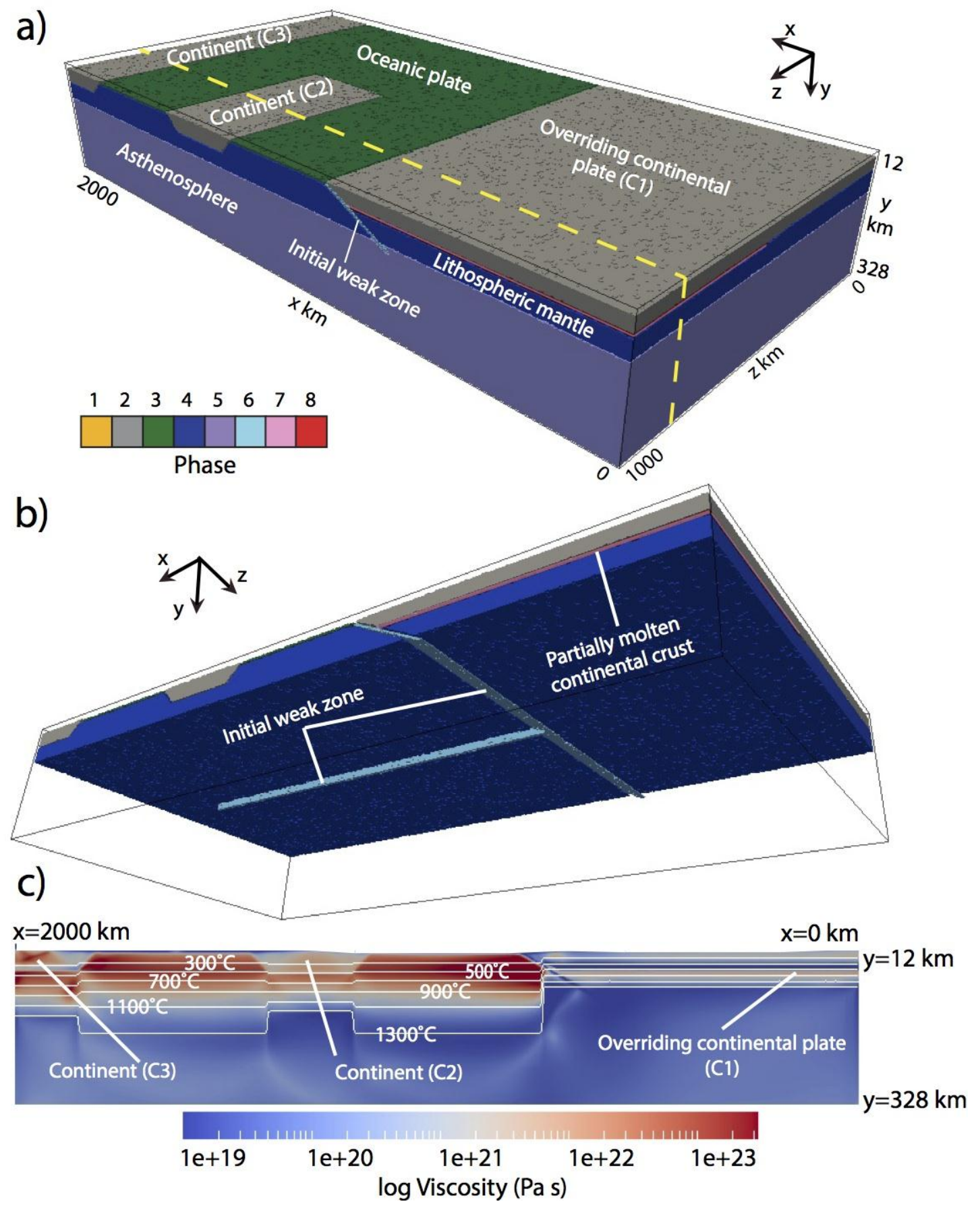

Figure 2: Model setup. a) The 3D model domain (2000x328x1000 km in the $\mathrm{x}, \mathrm{y}$ and $\mathrm{z}$ directions, respectively) with colours showing different rock types: 1-sediments; 2-continental crust; 3-oceanic crust; 4-lithospheric mantle; 5asthenospheric mantle; 6-hydrated/serpentinized mantle (initially imposed "weak fracture zone"); 7-partially molten continental crust; 8-partially molten mantle. The top layer ("sticky air", $\mathrm{y}<\sim 12 \mathrm{~km}$ ) and other phases are cut off for

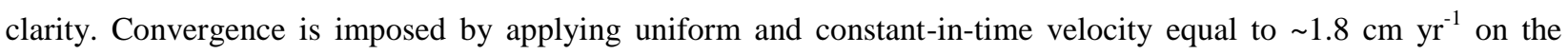


x=2000 km model boundary. b) Initial model domain and location of the "weak zones" (i.e., hydrated/serpentinized mantle) into the lithosphere to initialise subduction (z-parallel) and allow slab tearing (x-parallel). The bottom layer (asthenosphere, $y>\sim 105 \mathrm{~km}$ ) is cut off for clarity. c) $\mathrm{x}-\mathrm{y}$ viscosity profile of the initial model domain. The profile location is shown by the yellow dashed line in (a).

The evolution of the reference model is shown in Figure 3 and in Video S1, S2 and S3. The details and timing of the model evolution depends upon the assumed thermal and mechanical parameters (see the Supplementary Materials), but the overall sequence of events (Figure 3) is robust and includes: 1) early subduction of the oceanic domain between $\mathrm{C} 1$ and $\mathrm{C} 2$ and 2) later subduction of the oceanic domain between $\mathrm{C} 1$ and $\mathrm{C} 3$. These major events are allowed by tearing of the slab and separated in time by the collision between $\mathrm{C} 1$ and $\mathrm{C} 2$. Trench retreat, back-arc extension and progressive approach/collision of the continental plates characterize the surface evolution during the entire model run. 


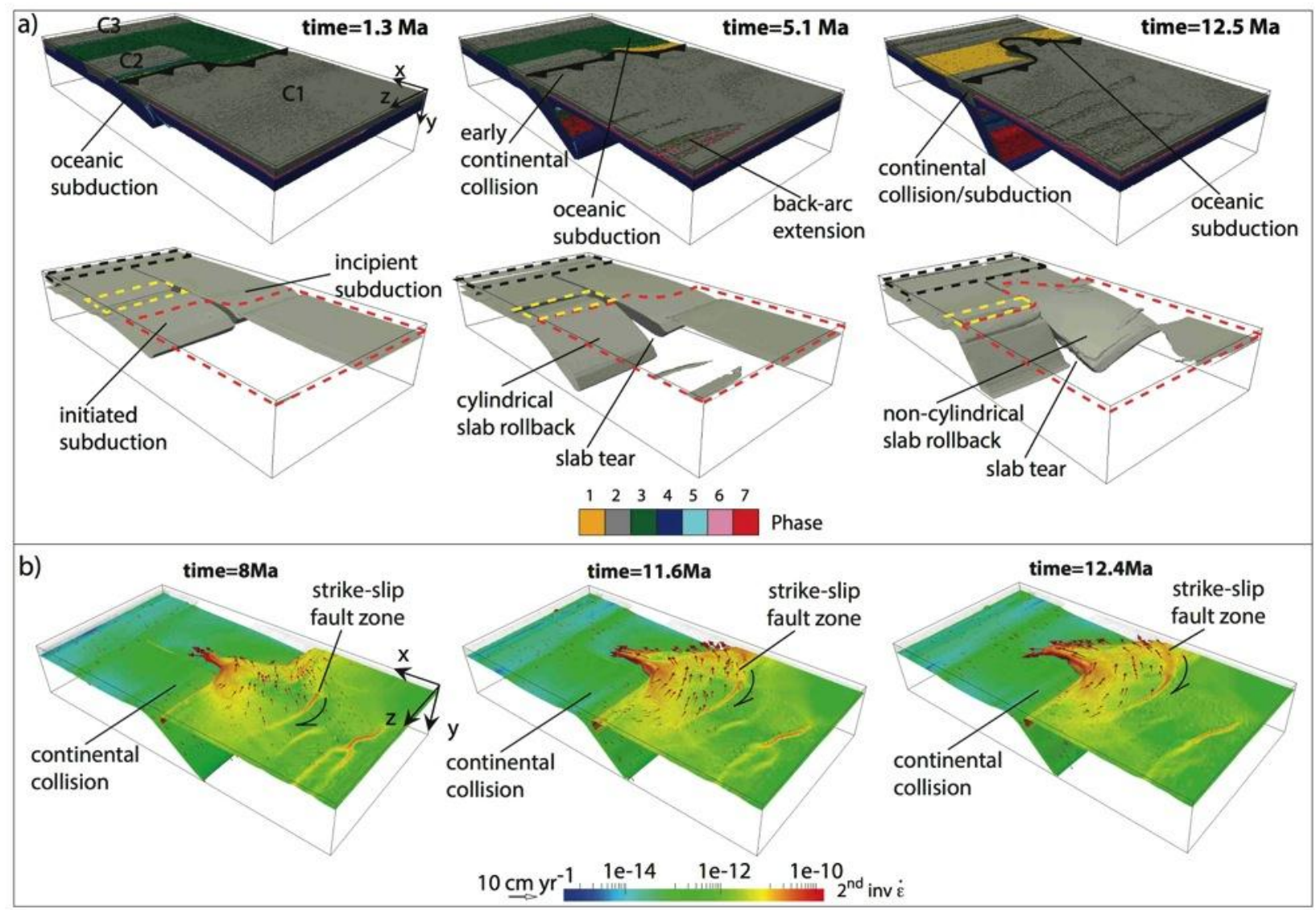

Figure 3: Evolution of the reference model. a) Colours on the top panels show different rock types: 1-sediments; 2continental crust; 3-oceanic crust; 4-lithospheric mantle; 5-hydrated/serpentinized mantle (initially imposed "weak fracture zone"); 6-partially molten continental crust; 7-partially molten mantle. The top layer ("sticky-air", y< 12 $\mathrm{km}$ ), the asthenosphere and other phases are cut off for clarity. The subducting plates shown on the bottom panels are visualised through an iso-viscosity contour equal to $10^{22} \mathrm{~Pa} \mathrm{~s}$. Red, yellow and black dashed lines on the lower panels show the plan view of $\mathrm{C} 1, \mathrm{C} 2$ and $\mathrm{C} 3$, respectively. b) Selected frames showing the $800^{\circ} \mathrm{C}$ isotherm (mostly corresponding to the crust-lithospheric mantle transition within the $\mathrm{C} 1$ domain), color-coded by the second invariant of the rate-of-strain tensor on this surface. A strike-slip fault zone (also visible at the surface, Figure 4b) is generated by the sub-horizontal mantle flow (red arrows) following slab rollback and tearing. Note that the timing of panels in (a) and (b) is different.

\section{Results}

In this section, we outline the numerical results with particular focus on the relationships 
between mantle and crustal flow and the effects of slab tearing and continental collision on the surface strain.

\subsection{Mantle vs. crustal flow}

A toroidal motion (with a minor ascending poloidal component) induced by the downgoing slab dominates the deep dynamics during the first subduction event (Figure 4a). This toroidal flow occurs both below $\mathrm{C} 1$ and through the opening slab window. At the surface, extensional and compressional deformation occurs in the back-arc and collisional domain, respectively. Crustal and mantle flows are essentially decoupled and surface deformation seems to be substantially driven by incipient slab rollback and trench retreat within the oceanic domain between $\mathrm{C} 1$ and $\mathrm{C} 3$ and continental collision between $\mathrm{C} 1$ and $\mathrm{C} 2$. The rheological stratification of the continental plates is essentially unaffected by this early subduction event, implying that the traction due to mantle flow is imposed at the base of the lithosphere (Figure 4c). 


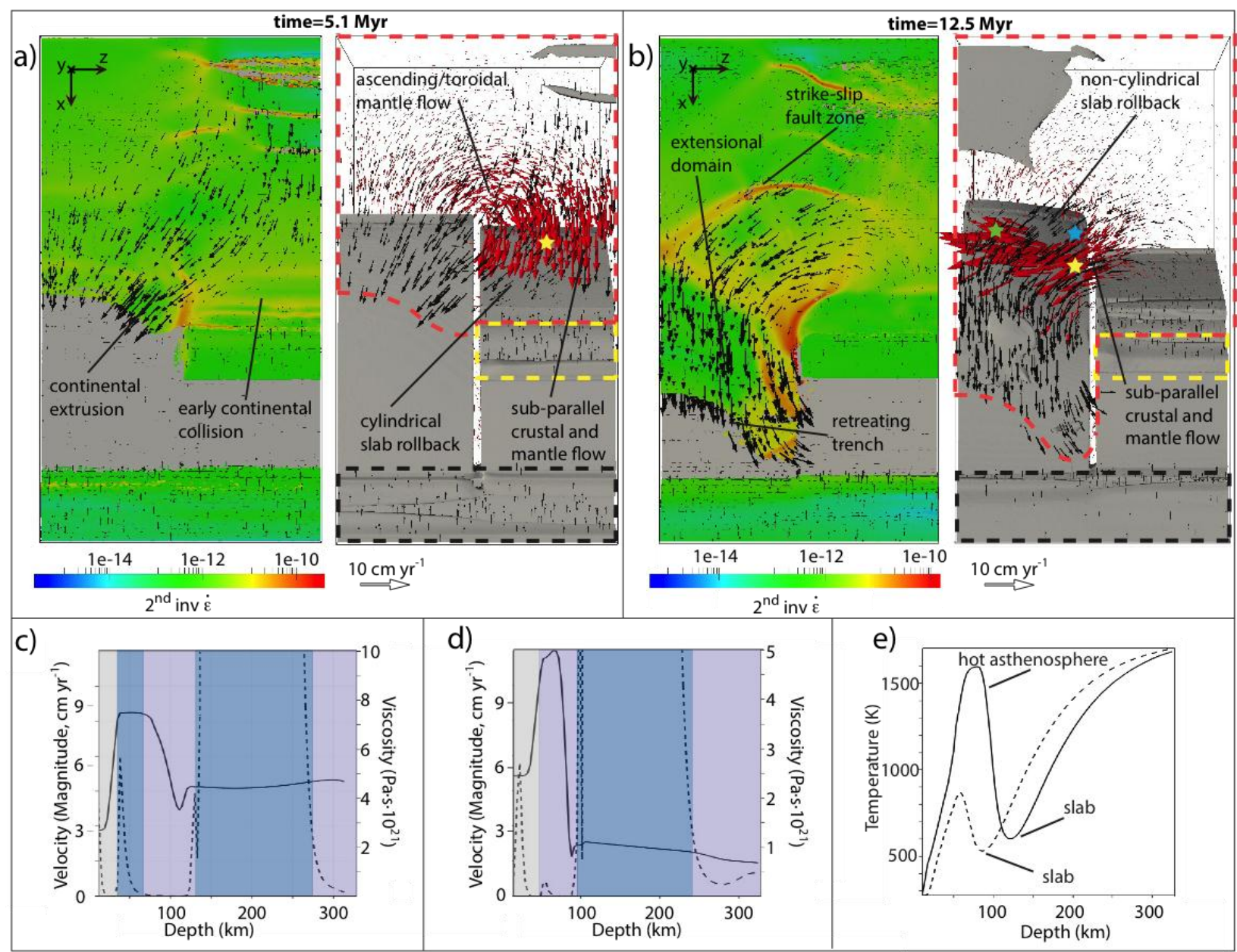

Figure 4: a-b) Plan view of selected temporal frames. Black and red arrows represent the velocity vectors in the continental crust and asthenosphere, respectively. Colours on the left panel show the second invariant of the rate-ofstrain tensor. The subducting plates are shown on the right panel through an iso-viscosity contour equal to $10^{22} \mathrm{~Pa}$ s. Red, yellow and black dashed lines on the right panels show the plan view of C1, C2 and C3, respectively. c-d) Depth-Velocity-Viscosity profiles (y-parallel). The profile location is shown by the yellow stars in (a) and (b). Solid lines, representing the magnitude of the velocity vector, follow the left-axis. Dashed lines, representing the viscosity, follow the right-axis. Shaded background colours show the phase at each depth: grey-continental crust, bluelithospheric mantle/slab, and purple-asthenospheric mantle. e) Temperature-depth profiles at $12.5 \mathrm{Ma}$ (the green and blue star in (b) shows the locations of the dashed and solid profile, respectively.

The model evolution during the second subduction event is highly conditioned by the 
precedent toroidal flow of hot asthenosphere. This flow warmed the incipiently subducting lithosphere close to the slab tear, enhancing here slab rollback and trench retreat, generating a non-cylindrical (i.e., not parallel to the initial upper plate margin) subduction (Figures 3, 4b and 4e). This subduction geometry induces a lateral (i.e., with non-nil trench-parallel component of motion), horizontal to sub-horizontal return flow of hot asthenospheric material, which further enhances the asymmetry of subduction (Figure 4b). The surface deformation across $\mathrm{C} 1$ is characterized at this stage by a faster trench retreat in the proximity of the collisional domain and above the slab tear, while localized strike-slip deformation propagating toward the subducting plate as the model progresses accommodates the rotation of a crustal block (Figure $3 b$ and $4 b$ ). The rheological stratification of the upper plate in the back-arc extensional domain is characterized by the absence of a rigid lithospheric mantle and the velocity-depth profile shows particularly fast mantle flow (Figure 4d), parallel in places to the surface velocity field (Figure $4 \mathrm{~b})$. This translates into shear stresses $\left(\sigma_{\mathrm{xy}}\right)$ up to $\sim 100 \mathrm{MPa}$ applied directly to the base of the crust by the asthenospheric flow (Figure 5). 

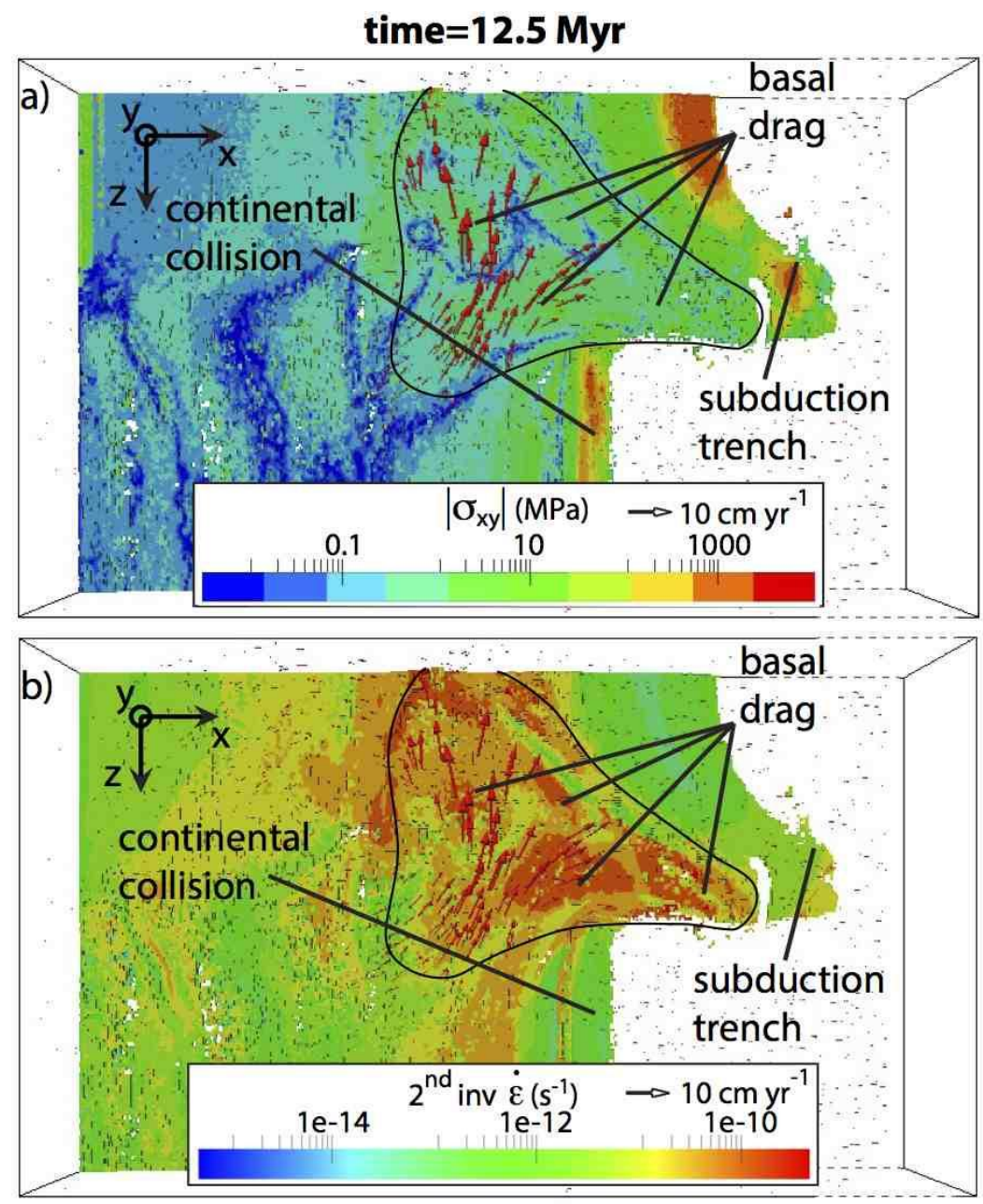

Figure 5: Shear stress (a) and strain rate (b) distribution at the base of the upper plate continental crust (C1) at 12.5 Myr modeled time on the reference simulation. Red arrows show the velocity field within the asthenosphere. The area inside the black line is where the asthenosphere is at direct contact with the base of the continental crust.

\subsection{Effects of slab tearing and continental collision on the surface strain}

By comparing the reference model outputs to similar simulations, but not implying collision between $\mathrm{C} 1$ and $\mathrm{C} 2$ or slab tearing, one can decouple the first-order crustal and mantle contributions to the surface strain. It appears that strain localization along a major strike-slip fault zone and thus the onset of a distinctive block-like deformation and surface rotation only occurs when both collision between rigid continental plates and slab tearing take place (Figures $4 \mathrm{~b}$ and 
6). In particular, the trench parallel component of motion within the upper plate is sensibly reduced in absence of continental collision or slab tearing. Besides, slab tearing allows/enhances rollback of the subducting plate, trench parallel/toroidal migration of the asthenosphere, trench retreat and extension within the upper plate.
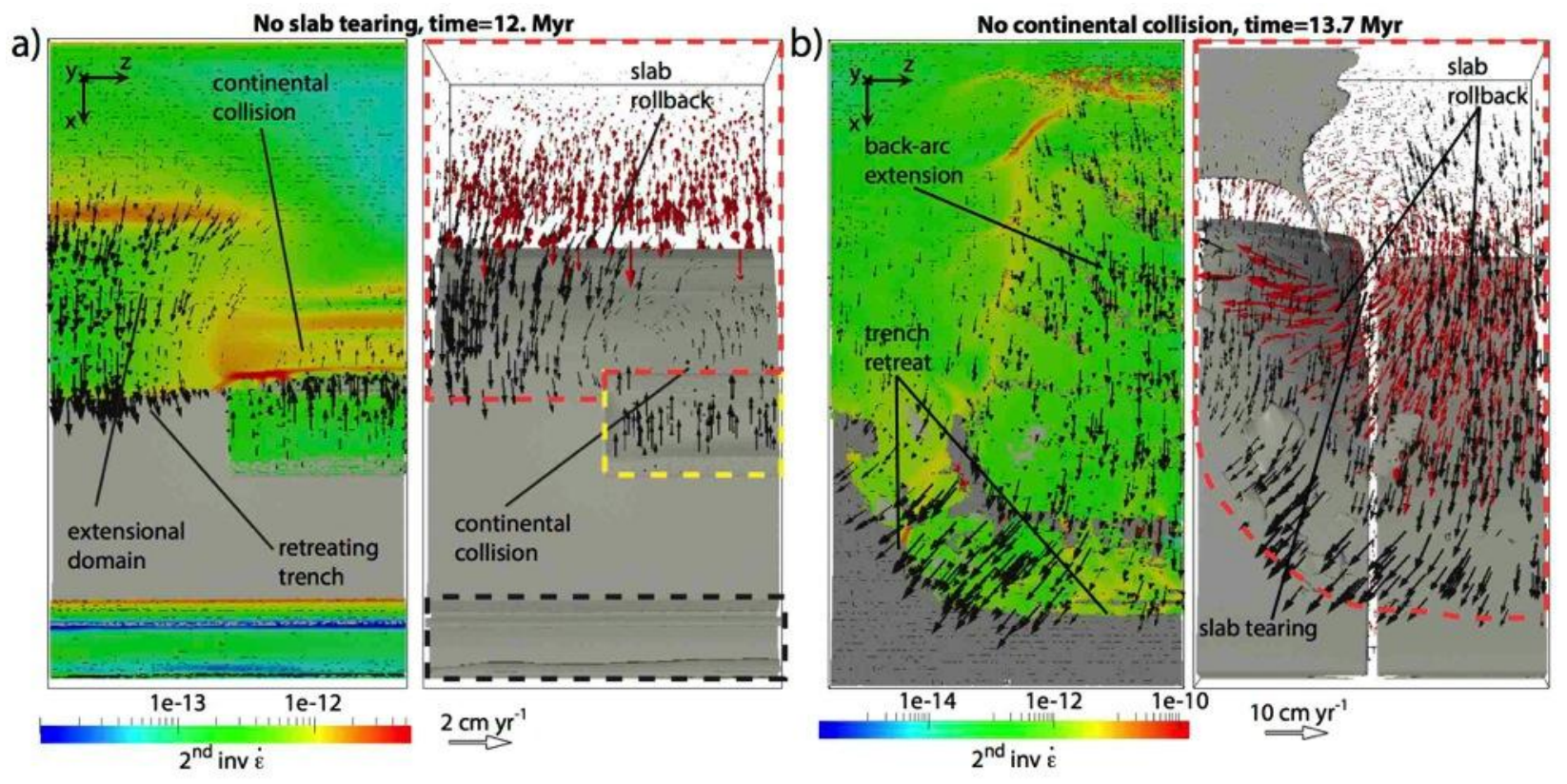

Figure 6: a) Plan view of a selected temporal frame of a simulation without slab tearing. b) Plan view of a selected temporal frame of a simulation without continental collision. Black and red arrows represent the velocity vectors in the continental crust and asthenosphere, respectively. Colours on the left panels show the second invariant of the rate-of-strain tensor. The subducting plates are shown on the right panel through an iso-viscosity contour equal to $10^{22} \mathrm{~Pa}$ s. Red, yellow and black dashed lines on the right panels show the plan view of C1, C2 and C3, respectively.

It is noteworthy that, when both continental collision and slab tearing allow for a blocklike deformation and surface rotation, the velocity fields within the crust and mantle are sensibly faster within the back-arc extensional region and close to the subduction trench than in the collisional domain (Figure 4b).

\section{Discussion}

Various combinations of processes such as extrusion tectonics, suction exerted by slab 
rollback, gravitational collapse of the collisional belt and mantle drag associated with regional plum-like upwelling were proposed to explain the observed surface kinematics across the Tethyan convergent domain (e.g., Tapponnier \& Molnar 1976; Royden 1997; Armijo et al. 1999; Allen et al. 2004; Alvarez 2010; Becker \& Faccenna 2011). Most of the proposed models, however, neglected the role played by the dynamical asthenospheric flow originated by slab rollback and tearing. A major outcome of our numerical experiments is that the toroidal motion of the asthenosphere at the edge of a retreating tearing slab is able to modulate the thermal state of the lithosphere, in turn affecting the geometry and dynamics of later subduction events and associated mantle and surface strain. Tectonic inheritance is clearly not a new concept, but it most often refers to the mechanical properties of the lithosphere and mantle (e.g., Thomas 2006), while we show here that also the thermal and kinematic inheritances can significantly affect the surface evolution. Moreover, the mantle return flow following slab rollback and tearing is able to produce tectonically significant (i.e., up to $100 \mathrm{MPa}$; Bürgmann \& Dresen 2008) shear stresses at the base of the lithosphere and crust. Thus, surface strain across subduction zones is likely to be jointly driven by slab rollback and mantle flow, especially across hot and thinned environments, characterized by the absence of a rigid mantle lithosphere such as the back-arc domains. It was demonstrated that the horizontal traction generated at the base of deep continental roots from regional thermal anomalies within the mantle dragged the continents together along the Tethyan axis and was able to protract convergence even after continental collision and brake-off of the Tethyan slabs (Alvarez 2010). The sub-horizontal mantle flow then seems to be able to actively drive the surface strain and kinematics across both thin and thick continental lithospheres. As such, the sub-horizontal couplings between the Earth's mantle and surface should benefit from the same attention that is paid to the vertical couplings and associated "dynamic topography" (e.g., Braun 2010). 
Our numerical experiments show that the surface strain at the transition between a continental indenter and an oceanic subduction can be dominated by the suction exerted by slab rollback (enhanced by slab tearing) and the associated mantle flow, as demonstrated by faster crustal flow close to the subduction trench than to the collisional domain (Figures 4b). Although the continental indenter is necessary for setting a block-like deformation and surface rotation, its role is that of a passive bulwark if the overall convergence rates are slower than slab rollback. Thus, the effectiveness of extrusion tectonics, crustal shortening and gravitational collapse at the margins of a collisional belt should be assessed in the light of the dynamics of the neighbouring oceanic subduction (Figure 7), since the "free boundary" is the most important factor controlling these mechanisms.

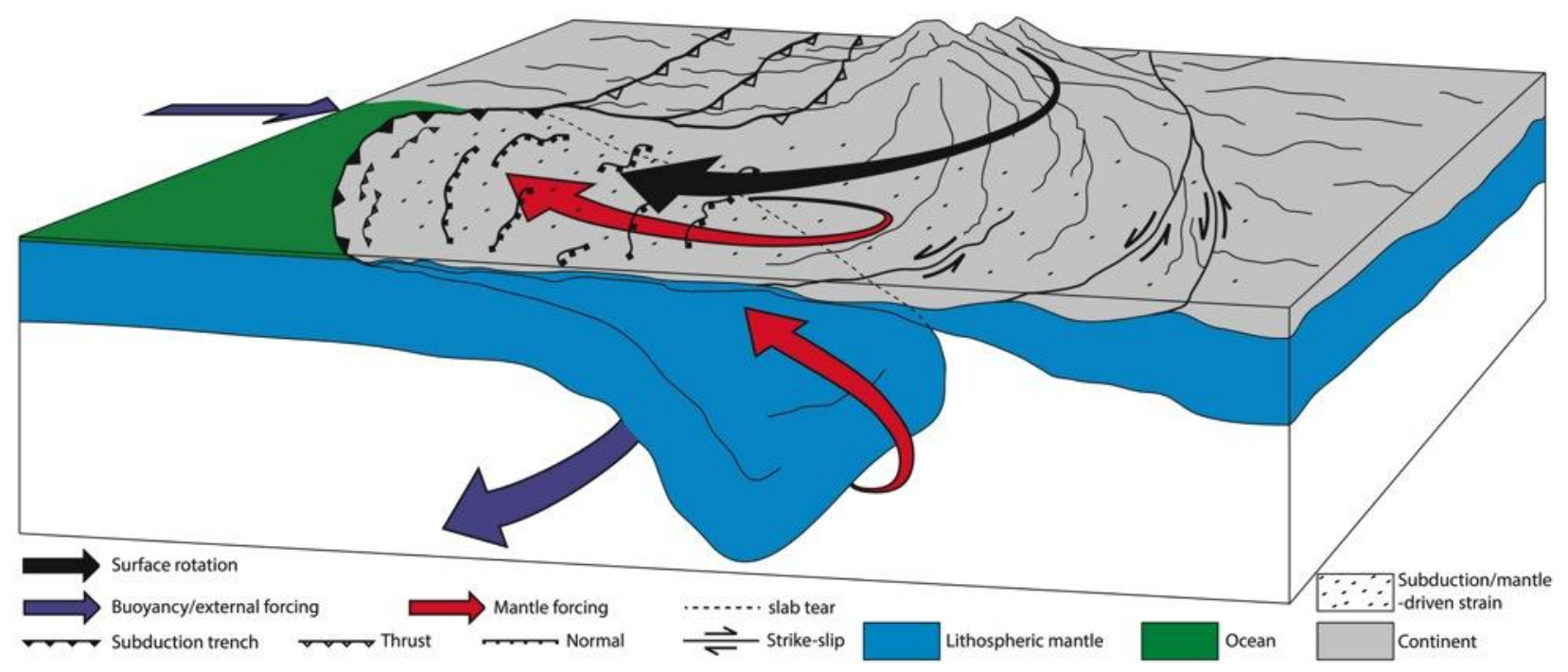

Figure 7: Illustrative representation of the dynamical interactions between continental collision, oceanic subduction, mantle flow and surface deformation.

We cannot resolve the timing of slab tearing across the Aegean-Anatolian or the eastern Indian-Eurasian margins nor can we address its relationships to slab rollback or continental collision through our modeling. However, trench migration rates are inversely correlated to the 
width of the subducting plate (Schellart et al. 2007), which implies that the observed tears decoupling the actively subducting slabs from the mantle lithosphere below the collisional domains might have facilitated slab rollback and modulated trench retreat after continental collision, consistently with our numerical experiments. A common feature in the Mediterranean metamorphic core complexes exhumed in back-arc domains from the lower and middle crust is a highly asymmetric deformation with constant sense of shear - i.e., hangingwall motion relative to footwall - (Jolivet et al. 2008; Jolivet, Faccenna \& Piromallo 2009). Our modeling results suggest that this asymmetric deformation is substantially controlled by the basal shear stresses imposed to the crust by the asthenospheric return flow.

The modeled surface velocity field shown in Figure $4 \mathrm{~b}$ is also similar (regardless of the sense of spin) to the observed surface rotation across the Aegean-Anatolian and the eastern Indian-Eurasian margins (Figure 1). The majority of the observed surface rotation across the natural examples is accommodated by several fault zones amongst which the NAF, the Kun-Lun, Xianshuihe-Xiaojiang and the Altyn Tagh faults (e.g., Sengör 1979; Tapponnier et al. 1982), whose kinematics is reasonably well reproduced in our numerical experiments by highly localised strike-slip deformation (Figures 3 and $4 \mathrm{~b}$ ). A faster crustal flow close to the subduction trench than to the collisional domain in our reference model is consistent with GPS measurements across the Aegean-Anatolian region, and suggests that the Aegean extension and extrusion of Anatolia are principally driven by the subduction dynamics and associated mantle flow, instead of collision-related mechanisms (Figure 7). The arrival of the Australian plate to the Sumatra trench in middle-late Miocene times (Ricou 1994) might have reduced the suction exerted by oceanic subduction. Nonetheless, the crust along portions of southeastern Tibet has been extending since at least 4 Myr (e.g., Royden 1997; Wang et al. 2001). The many basins and low topographies across the Sichuan, Yunan, Indochina and Sunda provinces as well as the back- 
arc basins further testify widespread extension, implying that the Andaman-Sumatra and other western Pacific subduction zones substantially affected the surface strain across southeastern Asia during most of the Cenozoic (Jolivet et al. 1990). In addition, tomographic models highlight the presence of hot and shallow asthenospheric material across southeastern Tibet (e.g., Li et al., 2008), which is analogous to the asthenosphere flowing at direct contact with the base of the crust and rotating around the edge of the collisional domain in our numerical experiments. Since a free boundary seems necessary to allow for continental extrusion (e.g., Tapponnier \& Molnar 1976; Tapponnier et al. 1982; Jolivet et al. 1990; Fournier et al. 2004) and this free boundary is provided by oceanic subduction which we proved able to actively drive the surface strain more efficiently than the continental indentation, our experiment confirm that the rollback of the Andaman-Sumatra and the associated mantle return flow actively determined the surface strain east and southeast of the EHS (Figure 7).

Instantaneous global flow models calculated from mantle density anomalies, suggest that both the pull from the Tethyan slabs and mantle upwelling from underneath the Ethiopia-Afar and Reunion-Carlsberg regions are necessary to reproduce the crustal motion across the Tethyan collisional belts (Becker \& Faccenna 2011; Faccenna et al. 2013). Our results suggest that the dynamical mantle flow associated solely with slab rollback and tearing can produce a distinct block-like surface rotation, without the intervention of an external dragging force such as the upwelling from the lower mantle. In our models, however, slab tearing is triggered along the preexisting weak oceanic fracture zones and modelled slabs are not tied to previously subducted plates as the Tethyan slabs probably were during most of the Cenozoic (Ricou 1994). Mantle upwellings, thus, have a major role in setting crustal motion at the scale of the whole Tethyan margins by dragging the northern and southern continents together along the Tethyan axis (Alvarez 2010), warming and propelling the upper continental plates (Becker \& Faccenna 2011; 
Faccenna et al. 2013) and, possibly, by thermally enhancing slab tearing, but the rollback of the Tethyan slabs and the associated mantle return flow are likely to be the primary drivers of the surface deformation at the edge of the Tethyan collisional belts.

\section{Conclusions}

3D Cartesian thermo-mechanical models of self-consistent oceanic subduction, slab tearing and continental collision calibrated on geologic, geophysical and geodetic observations and accounting for realistic crustal and mantle rheologies enabled us to conclude that:

- The dynamical asthenospheric flow originated by slab rollback and tearing is a primary factor controlling the surface evolution at the transition between collisional and subduction domains. In particular, the toroidal motion of the asthenosphere at the edge of a retreating tearing slab is able to modulate the thermal state of the lithosphere, in turn affecting the geometry and dynamics of later subduction events and associated mantle and surface strain. In addition, the sub-horizontal mantle return flow following slab rollback and tearing is able to produce tectonically significant shear stresses at the base of the lithosphere and crust. The surface strain across subduction zones is thus likely to be jointly driven by slab rollback and mantle flow, especially across hot and thinned environments such as the back-arc domains.

- The surface strain at the transition between a continental indenter and an oceanic subduction can be dominated by the suction exerted by slab rollback (enhanced by slab tearing) and the associated mantle flow. The continental indenter acts as a passive bulwark if the overall convergence rates are slower than slab rollback. Thus, the effectiveness of extrusion tectonics, crustal shortening and gravitational collapse at the margins of a collisional belt should be assessed in the light of the dynamics of the 
neighbouring oceanic subduction.

- A faster crustal flow close to the Hellenic subduction trench than to the collisional domain (consistently reproduced by our numerical models) suggests that the suction exerted by the Hellenic subduction and associated mantle flow is the principal driver of the Aegean extension and extrusion of Anatolia, instead of currently proposed collision-related mechanisms. Our experiment also confirm that the rollback of the Andaman-Sumatra and the associated mantle return flow affected the surface strain east and southeast of the EHS as also suggested by the several basins and low topographies across the Sichuan, Yunan, Indochina and Sunda provinces, which testify widespread extension.

- Mantle upwelling drag and propel the northern and southern continents along the Tethyan axis and possibly thermally enhance slab tearing. The rollback of the Tethyan slabs and the associated mantle return flow, however, are likely to be primary drivers of the surface deformation at the edge of the Tethyan collisional belts.

\section{Acknowledgements:}

This work has been financially supported by the Laboratoire d'Excellence (LABEX) VOLTAIRE of the University of Orléans and the European Research Council (ERC) under the $7^{\text {th }}$ Framework Programme of the European Union (ERC Advanced Grant, grant agreement No 290864, RHEOLITH). Numerical simulations were performed on the ETH-Zürich cluster BRUTUS. We are thankful to Claudio Faccenna and Thorsten Becker for stimulating discussions and to Kosuke Ueda for constructive comments on an early version of the manuscript and tips for the modelling. The paper benefited from insightful revision by Leigh Royden and two anonymous reviewers. 


\section{References}

Allen, M, Jackson, J \& Walker, R 2004, 'Late Cenozoic reorganization of the ArabiaEurasia collision and the comparison of short-term and long-term deformation rates ', Tectonics, vol 23, pp. doi:10.1029/2003TC001530.

Alvarez, W 2010, 'Protracted continental collisions argue for continental plates driven by basal traction', Earth and Planetary Science Letters, vol 296, pp. 434-442.

Armijo, R, Meyer, B, Hubert, A \& Barka, A 1999, 'Westward propagation of the north Anatolian into the northern Aegean: timing and kinematics ', Geology, vol 27(3), pp. 267270.

ArRajehi, A, McClusky, S, Reilinger, R, Daoud, M, Alchalbi, A, Ergintav, S, Gomez, F, Sholan, J, Bou-Rabee, F, Ogubazghi, G, Haileab, B, Fisseha, S, Asfaw, L, Mahmoud, S, Rayan, A, Bendik, R \& Kogan, L 2010, 'Geodetic constraints on present day motion of the Arabian Plate: implications for Red Sea and Gulf of Aden rifting', Tectonics, vol 29, pp. TC3011. doi:10.1029/2009TC002482.

Bürgmann , R \& Dresen, G 2008, 'Rheology of the lower crust and upper mantle: evidence from rock mechanics, geodesy, and field observations ', Annual Review of Earth and Planetary Sciences , vol 36, pp. 531-567.

Becker, T \& Faccenna, C 2011, 'Mantle conveyor beneath the Tethyan collisional belt', Earth and Planetary Science Letters, vol 310, pp. 453-461.

Braun, J 2010, 'The many surface expressions of mantle dynamics', Nature Geoscience, vol 3, pp. 825-833.

Burov, EB \& Watts, A 2006, 'the long-term strength of continental lithosphere: "jelly sandwich" or "crème brûlée"?', GSA Today, vol 16, no. 1.

Capitanio, F \& Replumaz, A 2013, 'Subduction and slab breakoff controls on Asian indentation tectonics and Himalayan western syntaxis formation', Geochemistry, Geophysics, Geosystems, vol 14, no. 9, pp. 3515-3531.

Davies, GF 1999, Dynamic Earth: Plates Plumes and Mantle Convection, Cambridge Univ. Press, Cambridge.

De Boorder, H, Spakman, W, White, SH \& Wortel, MJ 1998, 'Late Cenozoic mineralization, orogenic collapse and slab detachment in the European Alpine Belt', Earth and Planetary Science Letters, vol 164, no. 3, pp. 569-575.

Dewey, JF 1988, 'Lithospheric stress, deformation, and tectonic cycles: the disruption of Pangaea and the closure of Tethys', Geological Society, London, Special Publications, vol 37, no. 1, pp. 23-40.

Duretz, T, Gerya, T \& Spakman, W 2014, 'Slab detachment in laterally varying subduction zones: 3D numerical modeling', Geophysical Research Letters, vol DOI: $10.1002 / 2014 G L 059472$.

Faccenna, C \& Becker, T 2010, 'Shaping mobile belts by small-scale convection', Nature, vol 465, pp. 602-605.

Faccenna, C, Becker, TW, Conrad, CP \& Husson, L 2013, 'Mountain building and mantle dynamics', Tectonics, vol 32, pp. 80-93.

Faccenna, C, Becker, T, Jolivet, L \& Keskin, M 2013, 'Mantle convection in the Middle East: Reconciling Afar upwelling, Arabia indentation and Aegean trench rollback ', Earth and Planetary Science Letters, vol 375, pp. 254-269. 
Faccenna, C, Bellier, O, Martinod, J, Piromallo, C \& Regard, V 2006, 'Slab detachment beneath eastern Anatolia: A possible cause for the formation of the North Anatolian fault ', Earth and Planetary Science Letters, vol 242, pp. 85-97.

Fournier, M, Jolivet, L, Davy, P \& Thomas , J 2004, 'Backarc extension and collision: an experimental approach to the tectonics of Asia', Geophysical Journal International, vol 157, no. 2, pp. 871-889.

Gan, W, Zhang, P, Shen, Z, Niu, Z, Wang, M, Wan, Y, Zhou, D \& Cheng, J 2007, 'Present day crustal motion within the Tibetan Plateau inferred from GPS measurements', J. Geophys. Res., vol 113.

Gerya, T 2010, Introduction to Numerical Geodynamic Modelling, Cambridge University Press.

Gerya, T \& Yuen, D 2007, 'Robust characteristics method for modelling multiphase visco-elasto-plastic thermo-mechanical problems', Phys. Earth Planet. Inter., vol 163, pp. 83105.

Govers, R \& Wortel, MJ 2005, 'Lithosphere tearing at STEP faults: response to edges of subduction zones ', Earth and Planetary Science Letters , vol 236, pp. 505-523.

Holt, WE 2000, 'Correlated crust and mantle strain fields in Tibet', Geology, vol 28, no. 1, pp. 67-70.

Jackson, J 2002, 'Strength of the continental lithosphere: Time to abandon the jelly sandwich?', GSA Today.

Jolivet, L, Augier, R, Faccenna, C, Negro, F, Rimmele, G, Agard, P, Robin, C, Rossetti, F \& Crespo-Blanc, A 2008, 'Subduction, convergence and the mode of backarc extension in the Mediterranean region', Bull. Soc. géol. Fr. , vol 179, no. 6, pp. 525-550.

Jolivet, L, Davy, P \& Cobbold, P 1990, 'Right-lateral shear along the Northwest Pacific Margin and the India-Eurasia Collision', Tectonics, vol 9, no. 6, pp. 1409-1419.

Jolivet, L \& Faccenna, C 2000, 'Mediterranean extension and the Africa-Eurasia collision ', Tectonics, vol 19.

Jolivet, L, Faccenna, C \& Piromallo, C 2009, 'From mantle to crust: Stretching the Mediterranean ', Earth and Planetary Science Letters, vol 285, pp. 198-209.

Jolivet, L, Tamaki, K \& Fournier, M 1994, 'Japan Sea, opening history and mechanism, a synthesis', J. Geophys. Res., vol 99, pp. 22237-22259.

Jolivet, L, Faccenna, C, Huet, B, Labrousse, L, Le Pourhiet, L, Lacombe, O, Lecompte, E, Burov, E, Denèle, Y, Brun, J.-P., et al. 2013, 'Aegean Tectonics: strain localization, slab tearing and trench retreat', Tectonophysics, vol 597-598, pp. 1-33

Le Pichon, X, Fournier, M \& Jolivet, L 1992, 'Kinematics, topography, shortening and extrusion in the India-Eurasia collision', Tectonics, vol 11, no. 6, pp. 1085-1098.

Li, C, van der Hilst, R, Engdahl, ER \& Burdick, S 2008, 'A new global model for P wave speed variations in Earth's mantle', Geochemistry Geophysics Geosystems , vol 9, no. 5.

Li, C, van der Hilst, R, Meltzer, AS \& Engdahl, ER 2008, 'Subduction of the Indian lithosphere beneath the Tibetan Plateau and Burma', Earth and Planetary Science Letters, vol 274, pp. 157-168.

Li, Z, Xu, Z, Gerya, T \& Burg, JP 2013, 'Collision of continental corner from 3-D numerical modeling', Earth and Planetary Science Letters, vol 380, pp. 98-111. McKenzie, DP 1972, 'Active tectonics of the Mediterranean region ', Geophys. J. R. Astron. Soc., vol 30, pp. 109-185. 
Molnar, P \& Lyon-Caen, H 1988, 'Some simple physical aspects of the support, structure, and evolution of mountain belts ', Geol. Soc. Amer. Spec. Pap. , vol 218, pp. 179207.

Molnar, P \& Tapponnier, P 1975, 'Cenozoic tectonics of Asia: Effects of a continental collision', Science, vol 189(4201), pp. 419-426.

Nikolaeva, K, Gerya, T \& Marques, FO 2010, 'Subduction initiation at passive margins: Numerical modeling', Journal of Geophysical Research, vol 115, pp. doi:10.1029/2009JB006549.

Oldow, JS, Bally, AW \& Avé Lallemant, HG 1990, 'Transpression, orogenic float and lithospheric balance', Geology, vol 18, pp. 991-994.

Pérouse, E, Chamont-Rooke, N, Rabaute, A, Briole, P, Jouanne, F, Georgiev, I \& Dimitrov, D 2012, 'Bridging onshore and offshore present-day kinematics of central and eastern Mediterranean: Implications for crustal dynamics and mantle flow ', Geochemistry Geophysics Geosystems, vol 13(9), pp. doi:10.1029/2012GC004289.

Ranalli, G 1995, Rheology of the Earth, Deformation and Flow Processes in Geophysics and Geodynamics, Chapman \& Hall..

Reilinger, R, McClusky, S, Paradissis, D, Ergintav, S \& Vernant, P 2010, 'Geodetic constraints on the tectonic evolution of the Aegean region and strain accumulation along the Hellenic subduction zone', Tectonophysics, vol 488, pp. 22-30.

Replumaz, A, Guillot, S, Villaseñor, A \& Negredo, M 2013, 'Amount of Asian lithospheric mantle subducted during the India/Asia collision', Gondwana Research, vol 24, pp. 936-945.

Ricou, LE 1994, 'Tethys Reconstructed-Plates, Continental Fragments and Their Boundaries since 260-Ma from Central-America to South-Eastern Asia', Geodinamica Acta, vol 7, no. 4, pp. 169-218.

Royden, LH 1993, 'The tectonic expression slab pull at continental convergent boundaries', Tectonics, vol 12, no. 2, pp. 303-325.

Royden, L 1996, 'Coupling and decoupling of crust and mantle in convergent orogens: Implications for strain partitioning in the crust', J. Geophys Res., vol 101, pp. 679701.

Royden, L 1997, 'Surface Deformation and Lower Crustal Flow in Eastern Tibet ', Science, vol 276.

Royden , LH, Burchfiel, BC \& van der Hilst, RD 2008, 'The geological evolution of the Tibetan Plateau', Science, vol 321, pp. 1054-1058.

Ruddiman, WF 1997, Tectonic Uplift and Climate Change, Springer.

Schellart, WP, Freeman, J, Stegman, DR, Moresi, L \& May, D 2007, 'Evolution and diversity of subduction zones controlled by slab width', Nature, vol 446, pp. 388-311.

Sengör, AM 1979, 'The North Anatolian transform fault: its age, offset and tectonic significance ', J. Geol. Soc. (Lond.) , vol 136, pp. 269-282.

Tackley, P 2000, 'Mantle convection and plate tectonics: toward an integrated physical and chemical theory', Science, vol 288, pp. 2002-2007.

Tapponnier, P \& Molnar, P 1976, 'Slip-line field theory and large scale continental tectonics', Nature, vol 264, pp. 319-324.

Tapponnier, P, Peltzer, G, Le Dain, AY, R, A \& P, C 1982, 'Propagating extrusion tectonics in Asia: New insights from simple experiments with plasticine', Geology, vol 10, pp. 611-616. 
Tapponnier, P, Peltzer, G \& R. Armijo , R 1986, 'On the mechanics of the collision between India and Asia, in Collision tectonics', edited by M. P. Coward and A. C. Ries, pp. 115157.

Tapponnier, P, Zhiqin, X, Roger, B, Meyer, B, Arnaud, N, Wittlinger, G \& Jingsui , Y 2001, 'Oblique stepwise Rise and growth of the Tibet plateau', Science, vol 294, no. 5547, pp. 1671-1677.

Taylor, B \& Hayes, DE 1983, 'Origin and history of the South China Sea basin, in The tectonic and geologic evolution of southeast Asian seas and islands, part 2', edited by D. E. Hayes, AGU, Washington, D.C., pp. 23-56.

Thomas, WA 2006, 'Tectonic inheritance at a continental margin', GSA Today, vol 16, no. 2.

Tikoff, B, Russo , R, Teyssier, C \& Tommasi, A 2005, 'Mantle-driven deformation of orogenic zone and clutch tectonics. In: Grocott, J., McCaffrey, K.J.W., Taylor, G., Tikoff, B. (Eds.), Vertical coupling and decoupling in the lithosphere', Geological Society, London, Special Publications., pp. 41-64.

Turcotte, DL \& Schubert, G 2002, Geodynamics, Cambridge University Press, Cambridge.

van Hunen, J \& Allen, MB 2011, 'Continental collision and slab break-off: A comparison of 3-D numerical models with observations', Earth and Planetary Science Letters, vol 203, no. 1-2, pp. 27-37.

Wüstefeld, A, Bokelmann, GH, Barruol, G \& Montagner, JP 2009, 'Identifying global seismic anisotropy patterns by correlating shear-wave splitting and urface waves data', Phys. Earth Planet. Int., vol 176, no. 3-4, pp. 198-212.

Wang, Q, Zhang, P, Freymueller, JT, Bilham , R, Larson, KM, Lai, X, You , X, Niu, Z, Wu, J, Li, Y, Liu, J, Yang, Z \& Chen, Q 2001, 'Present-Day Crustal Deformation in China Constrained by Global Positioning System Measurements ', Science, vol 194.

Willett, SD 2006, Tectonics, climate, and landscape evolution, GSA Bookstore.

Zhang, ZK, Wang, M, Gan, W, Bürgmann, R, Wang, Q, Niu, Z, Sun, J, Wu, J, Hanrong, S \& Xinzhao, Y 2004, 'Continuous deformation of the Tibetan Plateau from global positioning system data', Geology, vol 32, pp. 809-812.

Zhong, S \& Gurnis, M 1995, 'Mantle convection with plates and mobile, faulted plate margins', Science, vol 267, pp. 838-843.

Zhu, G, Gerya, TV, Yuen, DA, Honda, S, Yoshida, T \& Connolly, JA 2009, '3-D dynamics of hydrous thermal-chemical plumes in oceanic subduction zones', Geochem. Geophys. Geosyst., vol 10, Q11006. 


\section{Supplementary Materials:}

Videos S1-S3 show the evolution of the reference model.
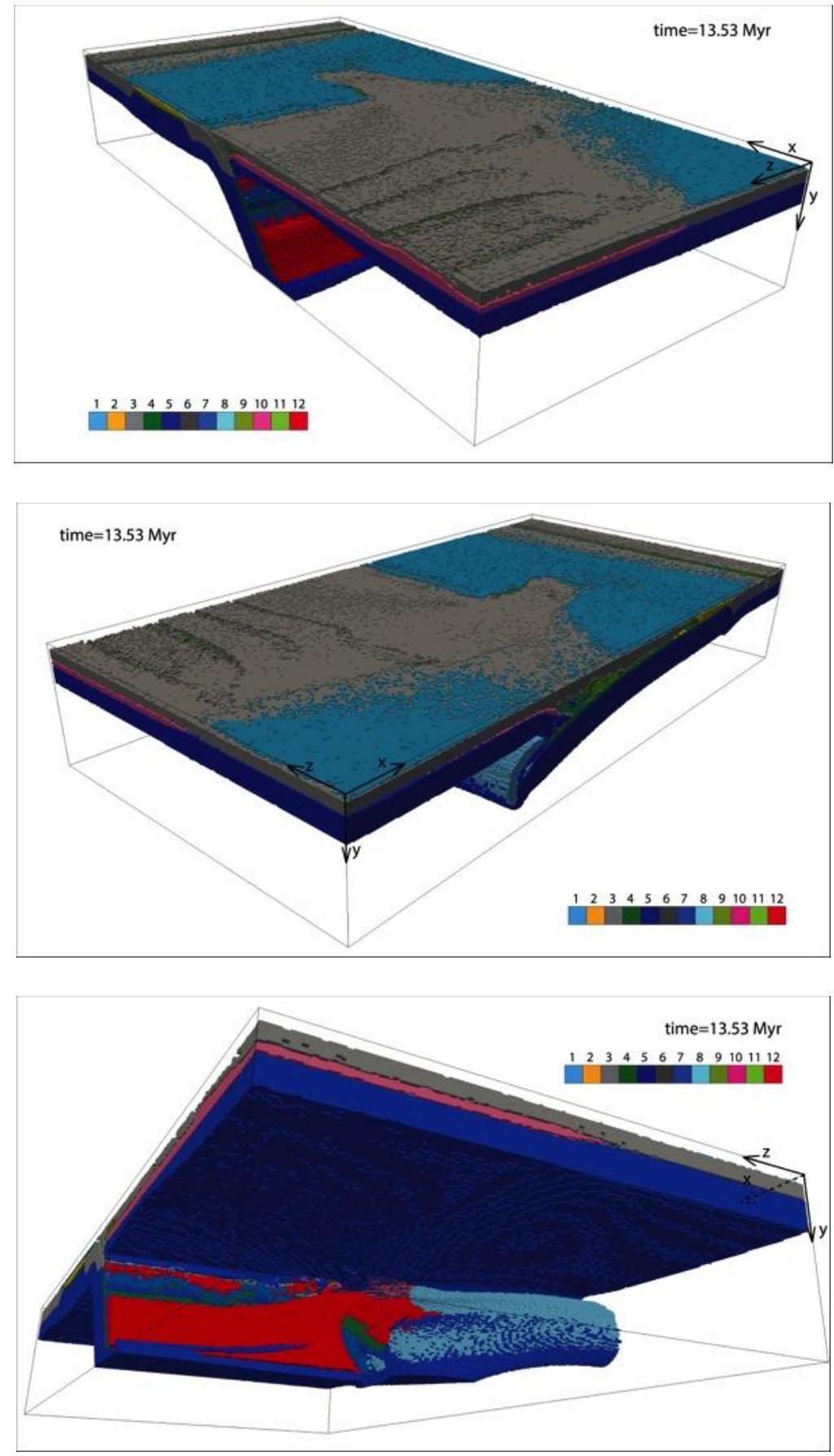

Video S1-S3: Evolution of the reference model (video thumbnails)

Our models are based on state-of-the-art numerical solutions for geodynamic problems 
(Gerya 2010) and experimentally derived deformation laws and parameters (Ranalli 1995). The natural complexity, however, is strongly simplified and major uncertainties arise from the imposed boundary conditions, the input parameters and the inferred distribution of the continental plates within the initial model setup. We here present a few of the additional computations we performed to establish that the model predictions and conclusions discussed in the text are robust with respect to these choices.

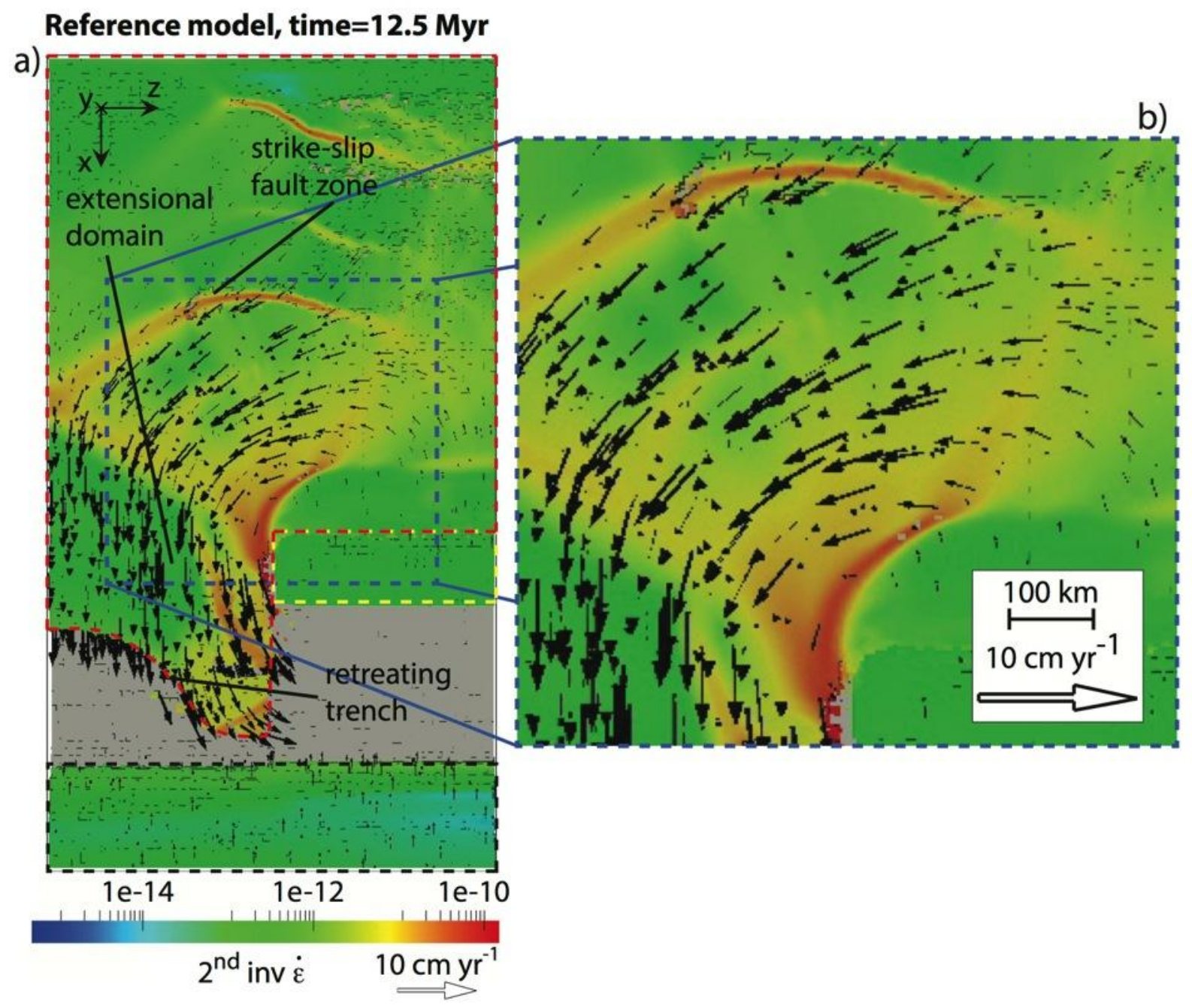

Figure S1: a) Same as the left panel of Figure 3b (reference model for comparison). Red, yellow and black dashed lines show the plan view of $\mathrm{C} 1, \mathrm{C} 2$ and $\mathrm{C} 3$, respectively. b) Zoom into the central part of the model domain to 
highlight the modeled surface velocity field originated by slab tearing and rollback (as discussed in the text), with limited influence from the imposed velocity boundary conditions.

The surface velocity field originated in the centre of the model domain by slab tearing and rollback (as discussed in the text) spreads over $\sim 800 \mathrm{~km}$ (Figure S1a,b) before approaching the edges of the model domain and being substantially modified by the imposed velocity boundary conditions. This distance is comparable to the distance between the western Bitlis-Zagros convergent domain and the eastern Hellenic subduction zone. We also stress that, at the stage of the model run shown by Figure S1, a rotational trajectory of the surface particles across $\mathrm{C} 1$ is the only possible since the indentation of $\mathrm{C} 2$ into $\mathrm{C} 1$ prevents the material from moving parallel to the $\mathrm{x}$-axis in the collisional domain and follow the flow imposed by slab rollback. Imposed influx or outflux across the $\mathrm{z}=0 \mathrm{~km}$ or $\mathrm{z}=1000 \mathrm{~km}$ boundaries, for example, would simply modify the geometry of such rotational motion. All discussions and conclusions presented in the text refer to this rotational motion within the central part of the model domain (Figure S1b).

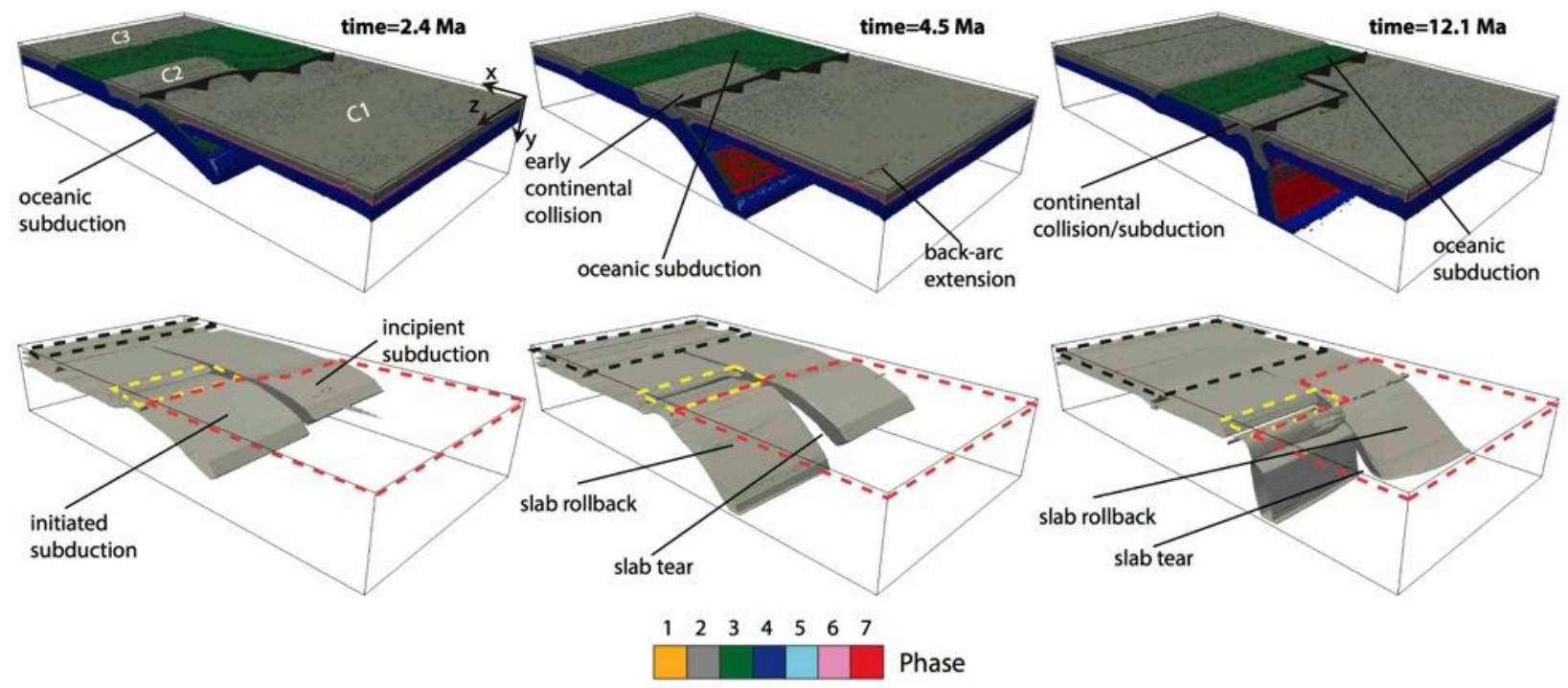

Figure S2: Sensitivity test for the imposed velocity boundary conditions. For each temporal frame, the phase distribution (1-sediments; 2-continental crust; 3-oceanic crust; 4-lithospheric mantle; 5-hydrated/serpentinized 
mantle (initially imposed "weak fracture zone"); 6-partially molten continental crust; 7-partially molten mantle) and the subducting plates are shown on the top and bottom panel, respectively. The top layer ("sticky air", $\mathrm{y}<\sim 12 \mathrm{~km}$ ), the asthenosphere and other phases are cut off for clarity. The subducting plates are visualised through an isoviscosity contour equal to $10^{22} \mathrm{~Pa}$ s. Red, yellow and black dashed lines on the lower panels show the plan view of

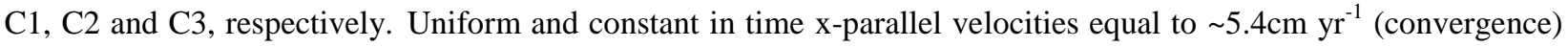
are imposed to the $\mathrm{x}=2000 \mathrm{~km}$ boundary. All other parameters are set as in the reference model.

We performed numerical experiments with $x$-parallel velocities imposed to the $x=2000 \mathrm{~km}$ boundary ranging between 0 and $5.4 \mathrm{~cm} \mathrm{yr}^{-1}$ (three time faster convergence rates than those of the reference model). In Figure S2 we show the numerical experiment in which uniform and constant

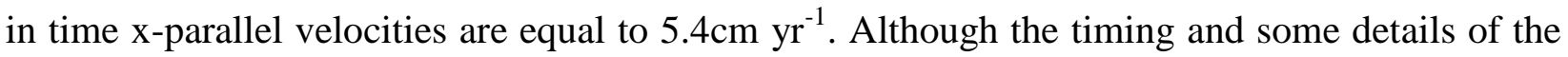
subduction dynamics differ from the reference model, the overall geodynamic evolution (see text) is similar in all simulations. Conclusions are thus robust with respect to the imposed velocity boundary conditions.

Nikolaeva and co-workers presented an extensive investigation of the parameters that codetermine the initiation and evolution of an ocean-continent subduction on a $2 \mathrm{D}$ version of the numerical model used in this study (Nikolaeva, Gerya \& Marques 2010). They found that the lithospheric and the crustal thickness of the upper continental plate is of primary importance. We ran simulations in which the initial $1300^{\circ} \mathrm{C}$ isotherm of the upper continental plate $(\mathrm{C} 1)$ is at 50 , $60,70,80,100$ and $110 \mathrm{~km}$ depth and the thickness of the crust varies between $25-55 \mathrm{~km}$ where $\mathrm{z} \leq 490 \mathrm{~km}$ and $35-65 \mathrm{~km}$ where $\mathrm{z}>510 \mathrm{~km}$ (linear interpolation in between). Overall, increased thickness of the continental crust enhances subduction rates and leads to a faster geodynamic evolution. On the contrary, an increased lithospheric thickness leads to slower subduction rates and overall evolution. Modern GPS data were used to calibrate the numerical experiments with respect to the crustal and lithospheric thicknesses. The magnitude of the modeled surface 
velocities and GPS measurements is in a first approach similar when the lithospheric thickness is set to $90 \mathrm{~km}$ and a the crustal thickness is equal to $35 \mathrm{~km}$ where $\mathrm{z} \leq 490 \mathrm{~km}$ and $45 \mathrm{~km}$ where z $>510 \mathrm{~km}$, with linear interpolation in between (i.e., the reference model). We show in Figure S3 a numerical experiment in which the initial $1300^{\circ} \mathrm{C}$ isotherm is at $70 \mathrm{~km}$ depth and the crust is $30 \mathrm{~km}$ where $\mathrm{z} \leq 490 \mathrm{~km}$ and $40 \mathrm{~km}$ where $\mathrm{z}>510 \mathrm{~km}$, with linear interpolation in between. In Figure $\mathrm{S} 4$, the initial $1300^{\circ} \mathrm{C}$ isotherm is at $100 \mathrm{~km}$ depth and the crust is $35 \mathrm{~km}$ where $\mathrm{z} \leq 490 \mathrm{~km}$ and $45 \mathrm{~km}$ where $\mathrm{z}>510 \mathrm{~km}$, with linear interpolation in between. Although the timing and some details of the subduction dynamics differ from the reference model, the overall sequence of events (see text) is similar in all simulations. Conclusions are thus robust with respect to these parameters.

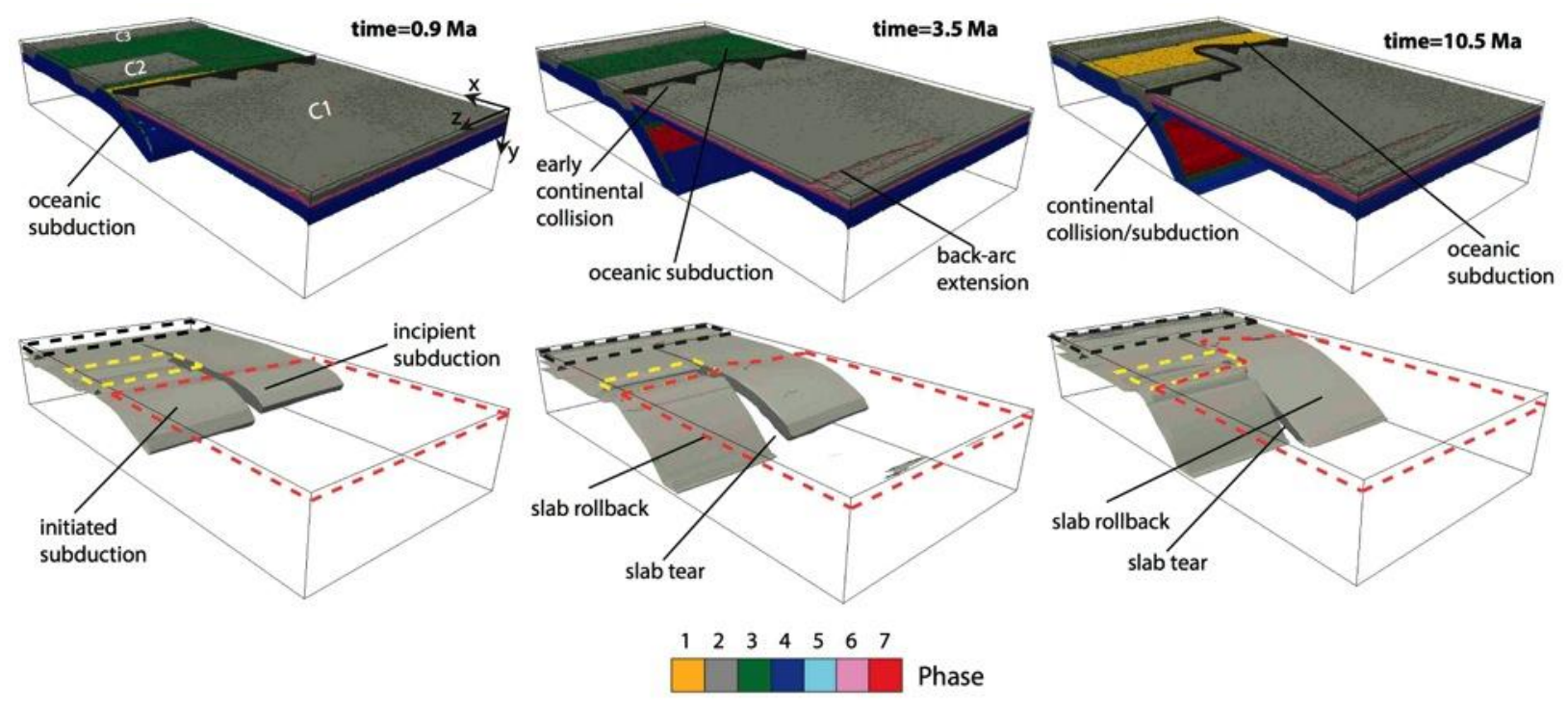

Figure S3: Sensitivity test for the geothermal gradient of the upper plate (C1). For each temporal frame, the phase distribution (1-sediments; 2-continental crust; 3-oceanic crust; 4-lithospheric mantle; 5-hydrated/serpentinized mantle (initially imposed "weak fracture zone"); 6-partially molten continental crust; 7-partially molten mantle) and the subducting plates are shown on the top and bottom panel, respectively. The top layer ("sticky air", $\mathrm{y}<\sim 12 \mathrm{~km}$ ), the asthenosphere and other phases are cut off for clarity. The subducting plates are visualised through an isoviscosity contour equal to $10^{22} \mathrm{~Pa}$ s. Red, yellow and black dashed lines on the lower panels show the plan view of 
$\mathrm{C} 1, \mathrm{C} 2$ and $\mathrm{C} 3$, respectively. The initial $1300^{\circ} \mathrm{C}$ isotherm is at $70 \mathrm{~km}$ depth and the crust is $30 \mathrm{~km}$ where $\mathrm{z} \leq 490 \mathrm{~km}$ and $40 \mathrm{~km}$ where $\mathrm{z}>510 \mathrm{~km}$, with linear interpolation in between.
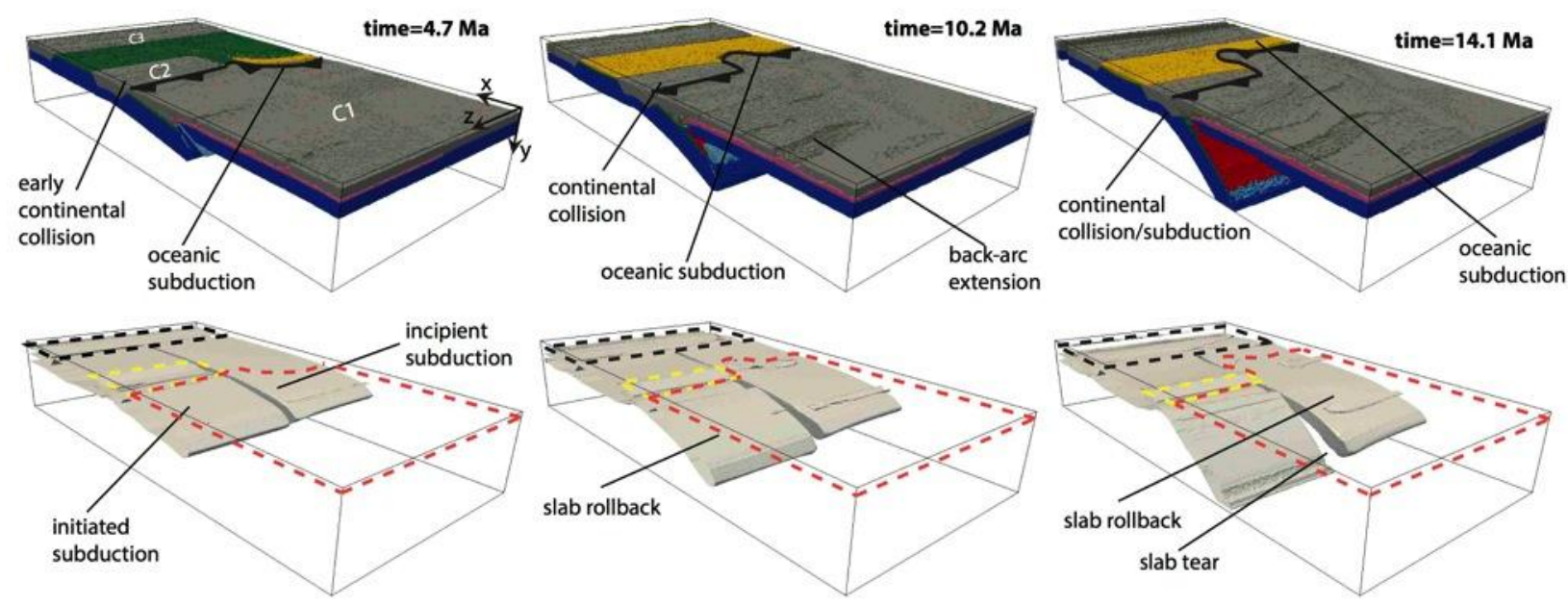

$\begin{array}{lllllll}1 & 2 & 3 & 4 & 5 & 6 & 7\end{array}$

Phase

Figure S4: Sensitivity test for the geothermal gradient of the upper plate (C1). For each temporal frame, the phase distribution (1-sediments; 2-continental crust; 3-oceanic crust; 4-lithospheric mantle; 5-hydrated/serpentinized mantle (initially imposed "weak fracture zone"); 6-partially molten continental crust; 7-partially molten mantle) and the subducting plates are shown on the top and bottom panel, respectively. The top layer ("sticky air", $\mathrm{y}<\sim 12 \mathrm{~km}$ ), the asthenosphere and other phases are cut off for clarity. The subducting plates are visualised through an isoviscosity contour equal to $10^{22} \mathrm{~Pa} \mathrm{~s}$. Red, yellow and black dashed lines on the lower panels show the plan view of $\mathrm{C} 1, \mathrm{C} 2$ and $\mathrm{C} 3$, respectively. The initial $1300^{\circ} \mathrm{C}$ isotherm is at $100 \mathrm{~km}$ depth and the crust is $35 \mathrm{~km}$ where $\mathrm{z} \leq 490 \mathrm{~km}$ and $45 \mathrm{~km}$ where $\mathrm{z}>510 \mathrm{~km}$, with linear interpolation in between.

In Figure S5 we show a sensitivity test for the inferred distribution of the continental plates, with particular focus on the role of continental collision in setting the patterns of surface deformation. All thermal and mechanical boundary conditions as well as the rheological parameters of this numerical experiment are the same as those of the reference model, the only difference being that $\mathrm{C} 1$ is the only continental plate within the model domain. Similarly to the 
reference model, the overall evolution of subduction is characterized by slab rollback and tearing as well as ascending toroidal mantle flows. However, the deformation of the upper plate in Figure $\mathrm{S} 5 \mathrm{~b}$ is sensibly less localised than in Figure 5a (i.e., the reference model) due to the lack of continental collision occurring on one side of the model domain. This test suggests that while slab rollback, tearing and consequent mantle flow control the surface deformation, continental collision allows the localisation of this deformation along one major strike-slip lineament (Figures 3 and 4), as discussed in the text.
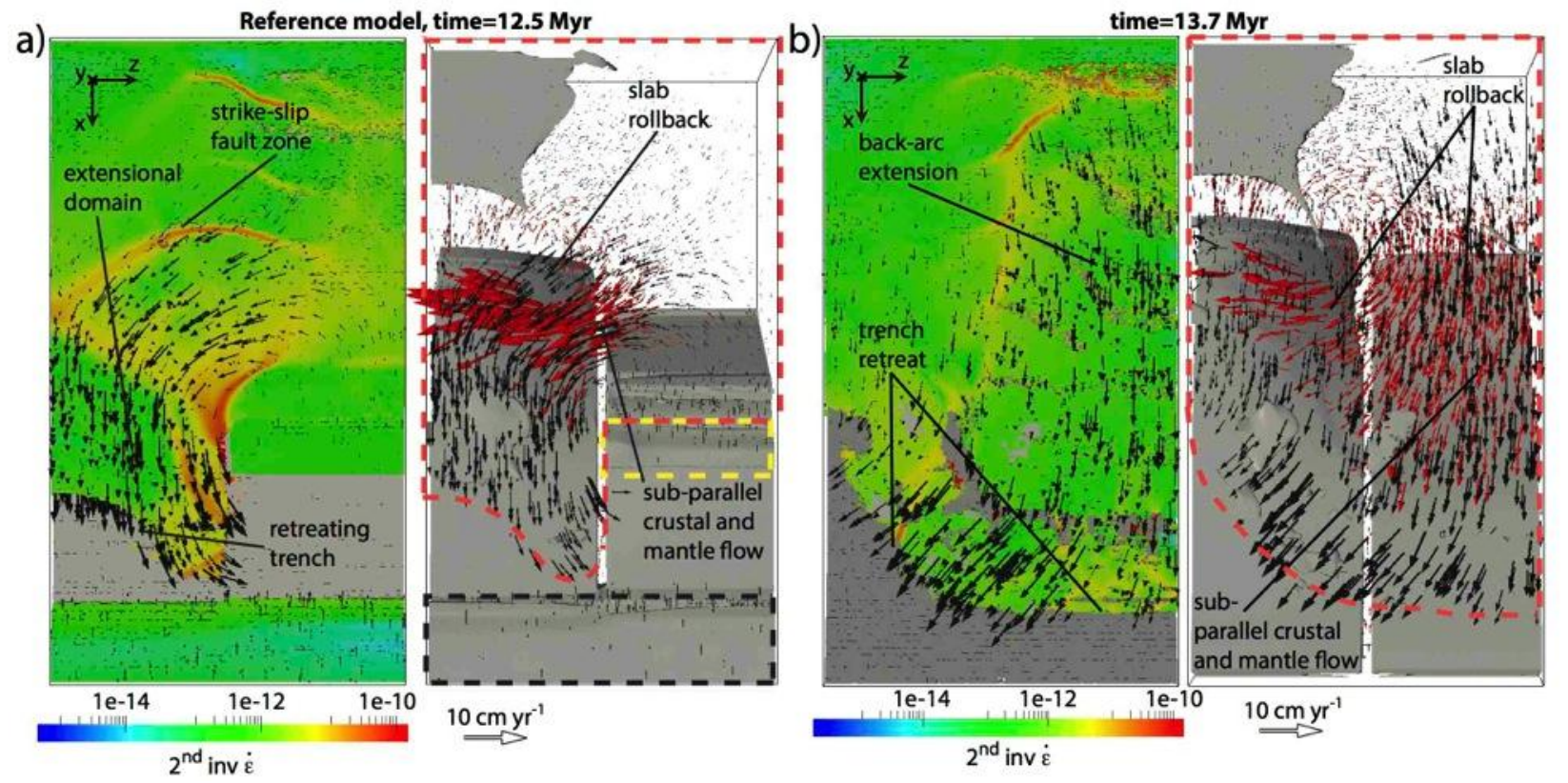

Figure S5: a) Same as Figure 3b (reference model for comparison). b) Plan view of a selected temporal frame of a simulation in which continental collision does not occur. Black and red arrows represent the velocity vectors in the continental crust and asthenosphere, respectively. Colours on the left panel show the second invariant of the rate-ofstrain tensor. The subducting plates are shown on the right panel through an iso-viscosity contour equal to $10^{22} \mathrm{~Pa}$ s. Red, yellow and black dashed lines on the right panels show the plan view of $\mathrm{C} 1, \mathrm{C} 2$ and $\mathrm{C} 3$, respectively.

In Figure S6 we show a sensitivity test for the process of slab tearing. All thermal and mechanical boundary conditions as well as the rheological parameters of this numerical experiment are the same as those of the reference model, the only difference being that we did 
not impose any weak fracture zone in the lithospheric mantle to allow for slab tearing. The deformation of the upper plate in Figure S6b is sensibly different than in Figure S6a (i.e., the reference model), which imply that slab tearing and associated mantle flow is a primary factor for the evolution of the surface strain and kinematics, as discussed in the text.
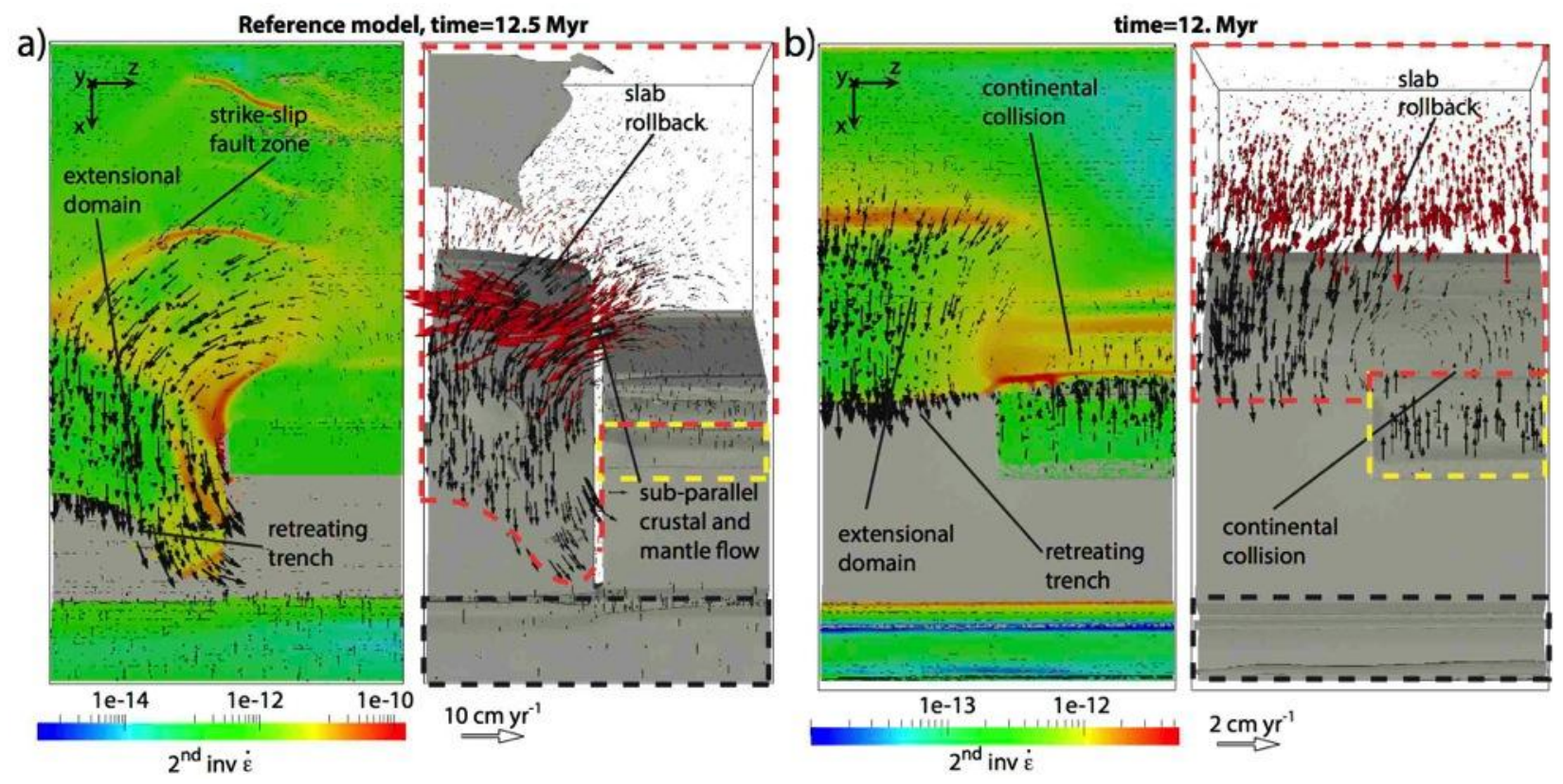

Figure S6: a) Same as Figure 3b (reference model for comparison). b) Plan view of a selected temporal frame of a simulation in which slab tearing does not occur. Black and red arrows represent the velocity vectors in the continental crust and asthenosphere, respectively. Colours on the left panel show the second invariant of the rate-ofstrain tensor. The subducting plates are shown on the right panel through an iso-viscosity contour equal to $10^{22} \mathrm{~Pa}$. Red, yellow and black dashed lines on the right panels show the plan view of $\mathrm{C} 1, \mathrm{C} 2$ and $\mathrm{C} 3$, respectively. 